\title{
Four new species of Kinorhyncha from the Gulf of California, eastern Pacific Ocean
}

\author{
Cepeda Diego ${ }^{1,{ }^{*}}$, Álvarez-Castillo Lucia ${ }^{2}$, Hermoso-Salazar Margarita ${ }^{2}$, Sanchez Nuria ${ }^{1,3}$, \\ Gomez Samuel ${ }^{4}$, Pardos Fernando ${ }^{1}$
}

\begin{abstract}
1 Departamento de Biodiversidad, Ecología y Evolución, Facultad de Ciencias, Biológicas, Universidad Complutense de Madrid. José Antonio Novais St. 12. 28040 Madrid (Spain)

${ }^{2}$ Facultad de Ciencias, Universidad Nacional Autónoma de México. Circuito Exterior S/N, 04510

México, D.F., Mexico

${ }^{3}$ Laboratoire Environnement Profond, Institut Français de Recherche pour, l'Exploitation de la Mer

(IFREMER), Centre Bretagne - ZI de la Pointe du Diable, CS 10070 - 29280 Plouzané (France)

4 Universidad Nacional Autónoma de México, Instituto de Ciencias del Mar y Limnología, Unidad

Académica de Mazatlán. Cap. Joel Montes Camarena, Cerro del Vigía. 82040 Mazatlán, Sin., Mexico

* Corresponding author : Diego Cepeda, email address : diegocepeda@ucm.es
\end{abstract}

\begin{abstract}
:
Several meiofaunal samples from the central and lower Gulf of California were studied. Four new species of kinorhynchs, Cristaphyes fortis sp. nov., Higginsium mazatlanensis sp. nov., Cephalorhyncha teresae sp. nov. and Echinoderes xalkutaat sp. nov., are described herein. Cristaphyes fortis sp. nov. may be distinguished from its most similar congeners by its more strongly developed pachycycli and ball-andsocket joints and the presence of unpaired paradorsal setae on segments 2, 4 and 6, two pairs of ventrolateral setae on segment 5 , one pair of ventrolateral setae on segments $2-4,6-7$ and 10 , and one pair of ventromedial setae on segments 8-9. Higginsium mazatlanensis sp. nov. is easily distinguished from its congeners by the combined presence of subdorsal setae only on segment 1 and lateroventral setae only on even segments. Cephalorhyncha teresae sp. nov. is unique within the genus by the presence of acicular spines in middorsal position on segments 4,6 and 8 , in sublateral position on segment 7 and in lateroventral position on segments 8 and 9, as well as tubes in subdorsal position on segment 2 , and in lateroventral position on segment 5 . Moreover, this species has primary pectinate fringes of segments $2-7$ bearing a tuft of elongated spinous projections in middorsal position, which is unique among its congeners. Echinoderes xalkutaat $\mathrm{sp}$. nov. belongs to a group of Echinoderes characterized by possessing type 2 glandular cell outlets in subdorsal, laterodorsal, sublateral and ventrolateral positions on segment 2, together with middorsal spines on segments 4-8, lateroventral spines on segments 6-9 and lateroventral tubes on segment 5 , but the arrangement of the remaining type 2 glandular cell outlets (in midlateral position on segment 5 , in sublateral position on segment 8 and in laterodorsal position on segment 10) and the cuticular composition of segment 11 (one tergal and two sternal plates) allow its morphological differentiation.
\end{abstract}

Keywords : Kinorhynchs, meiofauna, biodiversity, taxonomy, Pycnophyidae, Echinoderidae 
Kinorhynchs, commonly known as mud dragons, are marine, holobenthic, meiofaunal invertebrates that inhabit the upper centimetres of the bottom sea sediments (Neuhaus, 2013; Sørensen and Pardos, 2008). Species of kinorhynchs are distributed worldwide, and can be found from shallow waters to the deep sea (Neuhaus, 2013). Despite the apparent ubiquity of the phylum, only a few regions have been extensively sampled, and little is known about the true diversity and biogeography of these invertebrates (Grzelak and Sørensen, 2018; Neuhaus, 2013). Meiofaunal organisms are essential for the functioning of marine food webs and ecosystem (Gerlach, 1971; Hakenkamp and Morin, 2001; Schmid-Araya et al. 2002; Schratzberger and Ingels, 2017). The current lack of knowledge that hampers biodiversity estimations of meiofaunal taxa (Appeltans et al. 2012; Mokievsky and Azovsky, 2002) leads to the need of further taxonomic studies in order to improve our understanding of meiofaunal marine communities.

The Gulf of California represents an important gap in our knowledge on the distribution of Kinorhyncha from the eastern Pacific. The upper gulf has been recently studied by Álvarez-Castillo et al. (2015; 2018). They reported the kinorhynch Fissuroderes thermoi Neuhaus and Blasche, 2006 and the presence of ten additional unidentified kinorhynch species of the genus Echinoderes and the family Pycnophyidae. However, the central and lower gulf has received little attention, and the kinorhynch species composition of this part of the Gulf remains unexplored. The present contribution increases our knowledge on the diversity of Kinorhyncha in the central and lower Gulf of California with the description of two new Pycnophyidae and two new Echinoderidae species.

\section{Material and methods}

Sediment samples were collected at two localities in the central Gulf of California and one locality off Mazatlán, Sinaloa State, northwestern Mexico, lower gulf (Fig. 1; Table $1)$.

Samples from the central gulf were collected on February 11, 2007 during the course of oceanographic cruise Talud $\mathrm{X}$ on board of R/V El Puma (Universidad 
Nacional Autónoma de México). A sediment sample was collected at each station using a box corer, from which three replicas were taken using an acrylic corer of $9.2 \mathrm{~cm}$ of internal diameter and $19.5 \mathrm{~cm}$ long. The upper $3 \mathrm{~cm}$ layer of the sediment was recovered and preserved in $96 \%$ ethanol. Specimens of Kinorhyncha were firstly separated from the sediment particles and remaining meiofaunal organisms. Sample "St15" is located at $1570 \mathrm{~m}$ depth and the sediment was mainly composed of mud (sand: $4.49 \%$, silt: $84.00 \%$, clay: $11.96 \%$ ) with a low content of organic matter (8.37\%). Sample "St18" is located at $1440 \mathrm{~m}$ depth and the sediment was also composed of mud (sand: $17.20 \%$, silt: $71.62 \%$, clay: $11.19 \%$ ) with a low content of organic matter too $(7.13 \%)$.

The sediment sample from Mazatlán was taken at a sampling station located about 8.7 km south of Mazatlán on May 18, 2018 (sample “L3”). The sample was taken with a meiobenthic dredge during the Workshop "Técnicas de muestreo, morfología, taxonomía y análisis genético en meiofauna: Copépodos harpacticoides (Crustacea, Copepoda) y Kinorrincos (Cephalorhyncha, Kinorhyncha) como modelos", that took place at the Instituto de Ciencias del Mar y Limnología at Mazatlán. Sample "L3" is located at $5 \mathrm{~m}$ depth and the sediment was mainly composed of sandy mud. Meiofaunal organisms were separated from the sediment using the bubble-and-blot method (Higgins, 1964), and kinorhynchs were preserved in 100\% ethanol.

All the studied kinorhynch specimens were picked up under a Motic ${ }^{\circledR}$ SMZ-168 stereo zoom microscope with an Irwin loop and treated with a series of $25 \%, 50 \%, 75 \%$ and $100 \%$ glycerin for light microscopy (LM). The specimens were mounted on glass slides with Fluoromount $G^{\circledR}$ sealed with Depex ${ }^{\circledR}$. The specimens were studied and photographed using an Olympus ${ }^{\circledR}$ BX51-P microscope equipped with differential interference contrast (DIC) and an Olympus ${ }^{\circledR}$ DP-70 camera. Measurements were obtained with Olympus cellSens ${ }^{\circledR}$ software. Line drawings and image plates were prepared with Adobe ${ }^{\circledR}$ Photoshop CC-2014 and Illustrator CC-2014 software.

The type material was deposited in the collection of the Smithsonian National Museum of Natural History (NMNH), Washington.

\section{Results and discussion}


119 Taxonomic account

120 Class Allomalorhagida Sørensen et al., 2015

121 Family Pycnophyidae Zelinka, 1896

122 Genus Cristaphyes Sánchez et al., 2016

$123 \quad 3.1$ Cristaphyes fortis sp. nov.

124 (Figs. 2-5 and Tables 2-3)

urn:1sid:zoobank.org:act:1909D377-717B-4708-AA5F-176EA50569F8

\subsubsection{Type material}

127 Adult male holotype (USNM 1558492) collected on February 11, 2007 in the central

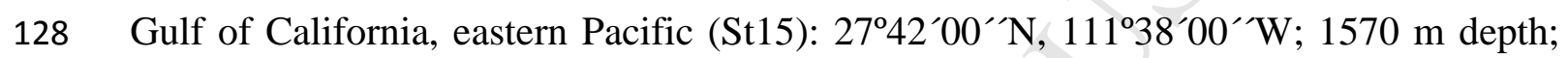

129 mounted in Fluoromount $G^{\circledR}$. One adult male paratype (USNM 1558494) with same

130 collecting data as holotype, and two adult females paratypes (USNM 1558495-

131 1558496) collected on February 12, 2007 in the central Gulf of California, eastern

132 Pacific (St18): $27^{\circ} 09^{\prime} 08^{\prime} \mathrm{N}, 111^{\circ} 39^{\prime} 57^{\prime} \mathrm{W}$; $1440 \mathrm{~m}$ depth; mounted in Fluoromount $133 \mathrm{G}^{\circledR}$.

\section{3.1.2 Diagnosis}

135 Cristaphyes with middorsal processes on segments 2-10; process of segment 10 shorter 136 and thinner than previous ones. Unpaired paradorsal setae on segments 2, 4 and 6. 137 Paralateral seta on segment 1; laterodorsal setae on segments 2-9, although those of 138 segments 5-7 and 9 may be absent or only present on one side; lateroventral setae on 139 segments 2, 4, 6, 8 and 10; two pairs of ventrolateral setae on segment 5 and one pair on 140 segments 2-4, 6-7 and 10; paired ventromedial setae on segments 8-9. Pachycycli and 141 ball-and-socket joints strongly developed, thick and stout, distinctly visible on segments $142 \quad 2-10$.

\subsubsection{Etymology}

144 The specific epithet from the Latin "fortis", strong or stout, refers to the markedly thick, 145 robust pachycycli and ball-and-socket joints of the new species.

\subsubsection{Description}


147 See Table 2 for measurements and dimensions, and Table 3 for summary of location of cuticular processes, setae, glandular cell outlets, spines, nephridiopores and sensory spots.

Head with retractable mouth cone and introvert (Fig. 3A-E). Although all the examined specimens had the introvert completely everted, oral styles and scalids tended to collapse when mounted for LM. There were no specimens for SEM examination, and only some details of the head structures are given. Observed inner oral styles composed of a single unit with a trapezoidal, enlarged base and a triangular, straight, rigid distal tip (Fig. 3C). Following ring (ring 00) with nine outer oral styles (Fig. 3D). Outer oral styles composed of a single, very flexible piece with a basal, short, fringed sheath (Fig. 3D-E). Exact arrangement and detailed morphology of these oral styles not determined. Ring 01 of introvert with ten primary spinoscalids, each one composed of a basal sheath and a distal, elongated piece; basal sheath equipped with a median, dense fringe (Fig. 3E). Remaining rings of introvert (rings 02-06) with scalids morphologically similar to the primary spinoscalids but shorter (Fig. 3E). Fourteen elongated, hairy trichoscalids without trichoscalid plates (Fig. 3E). Exact number, arrangement and detailed morphology of scalids not determined. placids rectangular; mesial ones broader than lateral ones (Fig. 2B). Ventral placids much more elongated and trapezoidal, progressively thinner laterally (Fig. 2A).

Trunk markedly rectangular, stout, strongly sclerotized, triangular in crosssection, composed of eleven segments (Figs. 2A-B and 3A-B). Segment 1 with one tergal, two episternal and one trapezoidal, midsternal plate conspicuously broader at its base (Figs. 2A-B and 3A-B); remaining segments with one tergal and two sternal, cuticular plates (Figs. 2A-B and 3A-B). Sternal plates reach their maximum width at segment 5, but are almost constant in width throughout the trunk, slightly tapering at the posterior trunk end (Figs. 2A-B and 3A-B). Middorsal processes on segments 2-10, keel-shaped, with enlarged, pointed tips that reach one quarter of the total length of the following plate on most segments; middorsal processes increase in width and length segment by segment towards the posterior trunk end (Figs. 2B and 3A); middorsal

178 Segments 1-10 with paired glandular cell outlets in subdorsal and ventromedial positions (ventromedial ones of segment 1 laterally shifted to ventrolateral position), 
near the anterior margin of segments, circular to oval-shaped (Figs. 2A-B, 4A-J and 5AJ). Segments 2-10 with paired, poorly-marked cuticular ridges in laterodorsal position and also at the ventrolateral-ventromedial limit, next to small glandular cell outlets (Fig. 2A-B, 4D, F, H, J and 5H, J). Muscular scars conspicuous, smooth, hairless, rounded to oval-shaped, in laterodorsal and ventromedial positions on segments 1-10 (except for the ventral muscular scars of segment 1 that are ventrolateral) (Figs. 2A-B, 4A-J and 5A-J). Pachycycli and ball-and-socket joints well-developed, thick, on segments 2-10 (Figs. 2A-B and 3A-B). Apodemes not observed. Posterior margin of segments straight, showing well-developed primary pectinate fringes weakly serrated; secondary pectinate fringes not detectable under LM (Fig. 2A-B).

Segment 1 without middorsal process (Figs. 2B and 3A). Anterolateral margins of the tergal plate as horn-shaped, straight, distally rounded extensions (Figs. 2A-B and 3A). Anterior margin of tergal plate strongly denticulated, followed by paired longitudinal grooves in subdorsal position (Figs. 2B and 4A). Paired setae in paralateral position (Figs. 2B and 4A). Paired sensory spots in laterodorsal and ventrolateral positions, distributed on the anterior half of segment, the former near the paralateral setae, the latter near the ventrolateral glandular cell outlets (Figs. 2A-B and 4A-B). Detailed morphology of sensory spots not determined.

Segment 2 with middorsal process projecting beyond the posterior margin of segment (Figs. 2B and 4C). Unpaired seta in paradorsal position (Figs. 2B and 4C); and paired setae in laterodorsal, lateroventral and ventrolateral positions (Figs. 2A-B and 4C-D). Two pairs of sensory spots in subdorsal position, one posterior to the subdorsal glandular cell outlets, the other mesial to muscular scars (Figs. 2B and 4C); and one pair of sensory spots in laterodorsal position (Figs. 2B and 4C). Sternal plates with two pairs of sensory spots in ventromedial position, lateral to the ventral muscular scars (Figs. 2A and 4D). Sexually dimorphic male tubes absent (Fig. 2A).

Segment 3 with middorsal process as on the preceding segment (Figs. 2B and 4E). Paired setae in laterodorsal and ventrolateral positions (Figs. 2A-B and 4E-F). Paired sensory spots in subdorsal, laterodorsal and ventromedial positions, with the laterodorsal pair lateral to the setae (Figs. 2A-B and 4E-F).

Segment 4 with middorsal process as on the preceding segment (Figs. 2B and 4G). Unpaired seta in paradorsal position (Figs. 2B and 4G); paired setae in 
212 laterodorsal, lateroventral and ventrolateral positions (Figs. 2A-B and 4G-H). Paired

213 sensory spots in subdorsal, laterodorsal and ventromedial positions, with the 214 laterodorsal pair lateral to the setae (Figs. 2A-B and 4G-H).

Segment 5 with middorsal process as on the preceding segment (Figs. 2B and 4I). One pair of setae in laterodorsal position (Figs. 2B and 4I), and two pairs of setae in ventrolateral position (Figs. 2A and $4 \mathrm{~J}$ ). Laterodorsal setae with intraspecific variation, absent in some specimens or present only on one side of the tergal plate. Paired sensory spots in subdorsal, laterodorsal and ventromedial positions, with the laterodorsal pair lateral to the setae (Figs. 2A-B and 4I-J).

Segment 6 similar to segment 4 in the arrangement of cuticular process, setae and sensory spots (Figs. 2A-B and 5A-B). Laterodorsal setae on this segment showing intraspecific variation as those of segment 5 .

Segment 7 similar to segment 5 in the arrangement of cuticular process, setae and sensory spots, except for the presence of a single pair of ventrolateral setae (Figs. 2A-B and 5C-D).

Segment 8 with middorsal process as on the preceding segment (Figs. 2B and 5E). Paired setae in laterodorsal, lateroventral and ventromedial positions (Figs. 2A-B and 5E-F). Paired sensory spots in subdorsal, laterodorsal and ventromedial positions, the latter mesial to ventromedial setae (Figs. 2A-B and 5E-F).

Segment 9 with middorsal process as on the preceding segment (Figs. 2B and 5G). Paired setae in laterodorsal and ventromedial positions (Figs. 2A-B and 5G-H). Laterodorsal setae with intraspecific variability, as those of segment 5. Paired sensory spots in subdorsal, laterodorsal and ventromedial positions (Figs. 2A-B and 5G-H), the latter lateral or mesial to the ventromedial setae. Paired nephridiopores in paralateral position; detailed morphology of nephridiopores not determined.

Segment 10 with short middorsal process, less developed than in previous segments (Figs. 2B and 5I). Paired setae in lateroventral and ventrolateral positions (Figs. 2A-B and 5J). Paired sensory spots in subdorsal and laterodorsal positions, near the posterior margin of segment (Figs. 2B and 5I). positions (Figs. 2B and 5K). Males with two pairs of stout, thick, penile spines and 
243 genital pores surrounded by a tuft of long hairs (Figs. 2A-B and 5L). Lateral terminal

244 spines long (LTS:TL average ratio $=29.0 \%$ ), slender, narrow, apparently rigid, with 245 rounded tips (Figs. 2A-B and 3A-B, F).

\subsubsection{Remarks on differential characters}

247 This species clearly belongs to the genus Cristaphyes by the following diagnostic features: middorsal processes on segments 2-10, surpassing the posterior margin of segments, progressively longer towards segment 9, and well-developed pachycycli and ball-and-socket joints of similar size on segments 2-10 (Sánchez et al. 2016). However, it may be distinguished from the remaining congeners by its unique arrangement of cuticular processes, setae and spines.

Cristaphyes fortis sp. nov. is characterized by having lateral terminal spines on segment 11 , and by lacking ventromedial, sexually dimorphic tubes in males, structures that are usually present in the family Pycnophyidae (Sánchez et al. 2016). Only $C$. chilensis (Lang, 1953), C. cornifrons Cepeda et al., this issue, C. longicornis (Higgins, 1983) and C. nubilis (Sánchez et al., 2014), share the combination of missing tubes and possessing lateral terminal spines with the new species. Moreover, $C$. fortis sp. nov., $C$. cornifrons and $C$. longicornis share the arrangement of middorsal processes throughout segments 2-10, whereas the middorsal processes of $C$. chilensis and C. nubilis are present from segment 1 .

Cristaphyes fortis sp. nov. can be distinguished from $C$. cornifrons and $C$. longicornis by its pattern of setae and spines. Cristaphyes longicornis is characterized

264 by having unpaired setae in paradorsal position on segments $2,4,6$ and 8 , whereas $C$. 265 fortis sp. nov. possesses these unpaired paradorsal setae only on segments 2, 4 and 6. 266 Moreover, C. longicornis has one pair of ventrolateral setae on segments 2, 5 and 10 and one pair of ventromedial setae on segments 1 and 3-9, while the new species has two pairs of ventrolateral setae on segment 5, one pair of ventrolateral setae on segments 2-4, 6-7 and 10, and one pair of ventromedial setae on segments 8-9. Cristaphyes cornifrons is even more similar to C. fortis sp. nov. in the arrangement of

271 the tergal setae, but differs remarkably on the sternal ones. Thus, $C$. cornifrons is characterized by having one pair of ventrolateral setae on segments $2-3,5$ and 10 (the last one only in females) and one pair of ventromedial setae on segments 4-9, whereas 
275 ventrolateral setae on segments $2-4,6-7$ and 10 , and one pair of ventromedial setae on

276 segments 8-9.

277

278 Genus Higginsium Sánchez et al., 2016

$279 \quad 3.2$ Higginsium mazatlanensis sp. nov.

280 (Figs. 6-9 and Tables 4-5)

281 urn:1sid:zoobank.org:act:0D79B812-D3CB-4CD9-8EE7-21361DF105A0

282 3.2.1 Type material

283 Adult male holotype (USNM 1558497) collected on May 18, 2018 near the mouth of 284 Presidio River, south of Mazatlán, Sinaloa State, Mexico (southern Gulf of California), 285 eastern Pacific (L3): $23^{\circ} 05^{\prime} 30^{\prime \prime} \mathrm{N}, 106^{\circ} 17^{\prime} 45^{\prime \prime} \mathrm{W} ; 5 \mathrm{~m}$ depth; mounted in Fluoromount $286 \mathrm{G}^{\circledR}$. Two adult males (USNM 1558499-1558500) and one adult female (USNM 287 1558498) paratypes with same collecting data as holotype; mounted in Fluoromount $288 \mathrm{G}^{\circledR}$.

289

290

291

292

293

294

295

296

297

298

299

300

301

302

\subsubsection{Diagnosis}

Higginsium with middorsal elevations on segments 1-6, middorsal processes on segments 7-9 and middorsal small pointed projection on segment 10. Anterior margin of first segment with several minute, rounded glandular cell outlets. Unpaired seta in paradorsal position on segments 3, 5, 7 and 9-10; paired setae in paradorsal position on segments 2, 4, 6 and 8. Subdorsal setae on segment 1. Two pairs of laterodorsal setae on segments 2-9, those of even segments more mesial than those of odd segments. Paralateral setae on segment 1. Lateroventral setae on segments 2, 4, 6, 8 and 10 (two pairs on segment 10). Ventromedial setae on segments 2-9. Male with paired, sexually dimorphic ventromedial tubes on segment 2 . Lateral terminal spines absent.

\subsubsection{Etymology}

The name makes refers to the municipality Mazatlán (Sinaloa State, Mexico), where the species was found.

\subsubsection{Description}


303 See Table 4 for measurements and dimensions, and Table 5 for summary of location of cuticular elevations, cuticular processes, setae, glandular cell outlets, nephridiopores and sensory spots.

Head with retractable mouth cone and introvert. The collected specimens were not suitable for head examination, hence data on number, morphology and arrangement of scalids and oral styles are not available.

Neck with four dorsal and two ventral sclerotized placids (Figs. 6A-C and 7CD). Dorsal placids trapezoidal, flattened, with a lateral indentation near the posterior margin; mesial ones broader, not getting narrower towards the lateral sides; lateral ones getting narrower towards the lateral sides, with a concave anterior margin (Figs. 6B and 7C). Ventral placids similar to dorsal mesial ones (Figs. 6A, C and 7D).

Trunk markedly rectangular, stout, sclerotized, triangular in cross-section, composed of eleven segments (Figs. 6A-B and 7A-B). Segment 1 with one tergal, two episternal and one midsternal plate; midsternal plate of segment 1 trapezoidal, laterally extended at its base, with a lateral constriction near its anterior margin, with a straight posterior margin (Figs. 6A-B and 7A-B, D). Remaining trunk segments with one tergal and two sternal plates (Figs. 6A-D and 7A-B). Sternal plates reach their maximum width at segment 6 , almost constant in width up to segment 9, progressively tapering towards the posterior end of trunk (Figs. 6A-B and 7A-B). Middorsal elevations on segments 1-6, short, pentagonally-shaped, distally rounded, not projecting beyond the posterior margin of segments, with intracuticular, butterfly-like atria of paradorsal sensory spots (Figs. 6A-B, 7A, 8A, C, E, G, I and 9A). Middorsal processes on segments 7-9, keel-shaped, with enlarged pointed tips, projecting beyond the posterior margin of segments, progressively longer in the last segments (Figs. 6B, 7A and 9C, E, G). Segment 10 also with a small, slightly pointed, very narrow middorsal elevation (Figs. 6B and 9I). Tergal plates of segments 1-10 with paired glandular cell outlets in subdorsal and ventromedial positions (ventral ones of segment 1 in ventrolateral position), near the anterior margin of segments, triangular to crescentic-shaped (Figs. 6A-C, 8A-J and 9A-J). Tergal plates of segments 2-7 with minute, rounded glandular cell outlets in laterodorsal position near the anterior margin of segments (Figs. 6B, 8C, E, G, I and 9A, C). Sternal plates of segments 2-10 with paired cuticular ridges marking the ventrolateral-ventromedial limit, quite inconspicuous on some segments, next to small glandular cell outlets (Figs. 6A, C, 8F, H, J and 9B, D, F, H). Segment 1 with 
several, minute, rounded glandular cell outlets, arranged dorsally along an anterior line running parallel to the anterior margin of segment, and ventrally in irregular patches (Figs. 6A-C and 8A-B). Muscular scars smooth, hairless, rounded to oval-shaped, in laterodorsal and ventromedial position on segments 1-10 (Figs. 6A-D, 8A-J and 9A-J). Pachycycli and ball-and-socket joints well-developed in segments 2-10 (Figs. 6A-D and 7A-B). Apodemes only slightly visible between segments 8-9, in paraventral position (Figs. 6A and 7B). Posterior margin of segments straight, with well-developed primary pectinate fringes strongly striated; secondary pectinate fringes developed as three wavy, transverse bands (Figs. 6A-D).

Segment 1 with middorsal elevation not projecting beyond the posterior margin of segment (Figs. 6B and 8A). Anterolateral margins of the tergal plate as horn-shaped, short, narrow, straight, distally pointed extensions (Figs. 6A-C, 7A-B and 8B). Paired setae in subdorsal, paralateral and ventrolateral positions (Figs. 6A-C and 8A-B). Two pairs of sensory spots in subdorsal position; one pair immediately below the subdorsal glandular cell outlets, another pair lateral to the muscular scars (Figs. 6B and 8A). One pair of sensory spots in paradorsal, lateroventral and ventrolateral positions (Figs. 6A-C and 8A-B). Detailed morphology of sensory spots not determined.

Segment 2 with middorsal elevation as on the preceding segment (Figs. 6B and 8C). Two pairs of setae in laterodorsal position, more mesial than those of the following segment, aligned with the remaining laterodorsal pairs of setae of the even segments (Figs. 6B and 8C); one pair of setae in paradorsal, lateroventral, ventrolateral and ventromedial positions (Figs. 6A-C and 8C-D). Paradorsal pair of setae not transversally aligned, so one of the seta appears more anterior than the other (Figs. 6B and 8C). Paired sensory spots in paradorsal, subdorsal, laterodorsal and ventrolateral position (Figs. 6A-C and 8C-D). Sexually dimorphic male tubes in ventromedial position, lateral to the ventromedial glandular cell outlets, short and thick (Figs. 6A and 8D).

Segment 3 with middorsal elevation as on the preceding segment (Figs. 6B and 8E). Unpaired seta in paradorsal position (Figs. 6B and 8E). Two pairs of setae in laterodorsal position, more lateral than those of the preceding segment, aligned with the remaining laterodorsal pairs of setae of the odd segments (Figs. 6B and 8E). One pair of setae in ventrolateral and ventromedial positions (Figs. 6A and 8F). Two pairs of sensory spots in subdorsal position (Figs. 6B and 8E); one pair of sensory spots in paradorsal, laterodorsal and ventromedial position (Figs. 6A-B and 8E-F). 
Segment 4 with middorsal elevation as on the preceding segment (Figs. 6B and

370

371

372

373

374

375

376

377

378

379

380

381

382

383

384

385

386

387

388

389

390

391

392

393

394

395

396

397

398

399

8G). Two pairs of setae in laterodorsal position, aligned with the remaining laterodorsal pairs of setae of the even segments (Figs. 6B and 8G); one pair of setae in paradorsal, lateroventral, ventrolateral and ventromedial positions (Figs. 6A-B and 8G-H). Paradorsal pair of setae not transversally aligned, so one of the seta appears more anterior than the other (Figs. 6B and 8G). Two pairs of sensory spots in subdorsal position (Figs. 6B and 8G); one pair of sensory spots in paradorsal, laterodorsal and ventromedial position (Figs. 6A-B and 8G-H).

Segment 5 with middorsal elevation as on the preceding segment (Figs. 6B and $8 \mathrm{I})$. Unpaired seta in paradorsal position, located on the opposite side of that of segment 3 (Figs. 6B and 8I). Two pairs of setae in laterodorsal position, aligned with the remaining laterodorsal pairs of setae of the odd segments, and in ventrolateral position (Figs. 6A-B and 8I-J); one pair of setae in ventromedial position (Figs. 6A and 8J). Two pairs of sensory spots in subdorsal position (Figs. 6B and 8I); one pair of sensory spots in paradorsal, laterodorsal and ventromedial position (Figs. 6A-B and 8I-J).

Segment 6 similar to segment 4 regarding the arrangement of cuticular elevation, setae and sensory spots (Figs. 6A-B and 9A-B).

Segment 7 with middorsal process projecting beyond the posterior margin of segment (Figs. 6B and 9C). Unpaired seta in paradorsal position, on the opposite side of that of segment 5 (Figs. 6B and 9C). Two pairs of setae in laterodorsal position, aligned with the remaining laterodorsal pairs of setae of the odd segments (Figs. 6B and 9C); one pair of setae in ventrolateral and ventromedial positions (Figs. 6A and 9D). Two pairs of sensory spots in subdorsal position (Figs. 6B and 9C); one pair of sensory spots in paradorsal, laterodorsal and ventromedial positions (Figs. 6A-B and 9C-D).

Segment 8 with middorsal process as in the preceding segment (Figs. 6B and 9E). Two pairs of setae in laterodorsal position, aligned with the remaining laterodorsal pairs of setae of the even segments (Figs. 6B and 9E); one pair of setae in paradorsal (not transversally arranged), lateroventral, ventrolateral and ventromedial positions (Figs. 6A-B and 9E-F). Three pairs of sensory spots in subdorsal position (Figs. 6B and $9 \mathrm{E}$ ); one pair of sensory spots in paradorsal, laterodorsal and ventromedial positions (Figs. 6A-B and 9E-F). 
Segment 9 with middorsal process as in the preceding segment (Figs. 6B and

401

402

403

404

405

406

407

408

409

410

411

412

413

414

415

416

417

418

419

420

421

422

423

424

425

426

427

428

429

430 9G). Unpaired seta in paradorsal position, on the opposite side of that of segment 7 (Figs. 6B and 9G). Two pairs of setae in laterodorsal position, aligned with the remaining laterodorsal pairs of setae of the odd segments (Figs. 6B and 9G); one pair of setae in ventrolateral and ventromedial positions (Figs. 6A and 9H). Three pairs of sensory spots in subdorsal position (Figs. 6B and 9G); one pair of sensory spots in paradorsal, laterodorsal and ventromedial positions (Figs. 6A-B and 9G-H). Paired nephridiopores in paralateral position; detailed morphology of nephridiopores not determined.

Segment 10 with slightly pointed, narrow middorsal elevation not surpassing the posterior margin of segment (Figs. 6B and 9I). Unpaired seta in paradorsal position, located on the opposite side of that of the preceding segment (Figs. 6B and 9I). Two pairs of setae in lateroventral position (Figs. 6A-B and 9J). Paired sensory spots in subdorsal, laterodorsal and ventromedial positions (Figs. 6A-B and 9I-J).

Segment 11 with paired type 3 sensory spots in subdorsal position, at the anterior half of segment (Figs. 6B and 9K). Posterior margin of segment of tergal plate straight, softly serrated; sternal plates form a pair of ventral extensions rounded distally (Figs. 6A-B, D and 9K-L). Male with two pairs of stout, thick, hairy penile spines (Figs. 6A-B and 9L). Lateral terminal spines absent.

\subsubsection{Remarks on differential characters}

Higginsium mazatlanensis sp. nov. agrees well with the diagnosis of the genus (Sánchez et al. 2016), which currently encompasses four species: H. cataphractum (Higgins, 1961), described from San Juan Archipelago, Washington State (northeastern Pacific); H. dolichurum (Sánchez et al., 2011), described from Ares Ria, Spain (northeastern Atlantic), and H. erismatum (Higgins, 1983) and H. trisetosum (Higgins, 1983), both described from Belize (Caribbean Sea).

Higginsium dolichurum is the species that most differs from H. mazatlanensis sp. nov., as lateral terminal spines are present in the former but absent in the latter. Similarly, $H$. dolichurum lacks sexually dimorphic tubes on the male segment 2 , which are present in the new species. The remaining species of the genus (H. cataphractum, $H$. erismatum and $H$. trisetosum) and $H$. mazatlanensis sp. nov. share the lack of lateral 
431 terminal spines and the presence of sexually dimorphic tubes in ventromedial position

432 on the male segment 2.

433

434

435

436

437

438

439

440

441

442

443

444

445

446

447

448

449

450

451

452

453

454

455

456

457

458

459

460

461

462

463

The available morphological information of $H$. cataphractum is rather scarce (Higgins, 1961), and several diagnostic traits that would allow to easier distinction of this species from its congeners could not be observed in the re-examination of the type material by Sánchez et al. (2016) because of the bad preservation of the specimens. However, H. cataphractum is characterized by having a single pair of laterodorsal setae on segments 2-9 and lateroventral setae on segments $2,4,6-8$ and 10 , while $H$. mazatlanensis sp. nov. has two pairs of laterodorsal setae on segments 2-9, one pair of lateroventral setae on segments 2, 4, 6 and 8 and two pairs on segment 10.

Higginsium erismatum possesses paired, paradorsal setae only on even segments, a single pair of laterodorsal setae on segments $2-9$, paired subdorsal setae on segments 2-9, paired ventrolateral setae on segments $1,5,7$ and 9 , whereas $H$. mazatlanensis sp. nov. is characterized by having unpaired paradorsal setae on segments 3, 5, 7 and 9-10, paired paradorsal setae on segments 2, 4, 6 and 8, two pairs of laterodorsal setae on segments 2-9, paired subdorsal setae only on segment 1, paired ventrolateral setae on segments 2-9. Additionally, the arrangement of ventromedial setae of $H$. erismatum is different in both sexes: the females possess these setae on segments 6-9, whereas males have ventromedial setae also on segments $3-5$, while both males and females of $H$. mazatlanensis sp. nov. have two pairs on segment 5 and one pair on segments 2-4 and 6-9.

Higginsium trisetosum is the species that resembles H. mazatlanensis sp. nov. the most. Both species have two pairs of laterodorsal setae on segments 2-9, midsternal plate of segment 1 with a mushroom-like appearance (due to a lateral constriction near its anterior margin) and secondary pectinate fringes of segments 2-9 composed of three transverse, wavy, softly serrated bands distributed throughout the anterior half of segments. Nevertheless, $H$. trisetosum has subdorsal setae on segments 2-9 and lateroventral setae on segments 1-10, whereas H. mazatlanensis sp. nov. has subdorsal setae only on segment 1 and lateroventral setae only on even segments. Moreover, the sternal plates of $H$. trisetosum have ventrolateral setae on segments 1 and 3-9, and ventromedial setae on segment 3-9 (females also on segment 2), while those of $H$. mazatlanensis sp. nov. bear ventrolateral setae on segments 1-9 and ventromedial setae on segments 2-9 (both males and females). 
Another morphological feature that allows distinguishing $H$. mazatlanensis sp.

465

466

467

468

469

470

471

472

473

474

475

476

477

478

479

480

481

482

483

484

485

486

487

488

489

490

491

492 nov. from its congeners is the possession of several, minute, rounded glandular cell outlets distributed near the anterior margin of the tergal plate of segment 1 and throughout the surface of the sternal plates of segment 1 . These glandular cell outlets are absent in other species of Higginsium.

Class Cyclorhagida (Zelinka, 1896) Sørensen et al., 2015

Family Echinoderidae Zelinka, 1894

Genus Cephalorhyncha Adrianov, 1999 in Adrianov and Malakhov, 1999

\subsection{Cephalorhyncha teresae sp. nov.}

(Figs. 10-12 and Tables 6-7)

urn:1sid:zoobank.org:act:260F18A5-472F-47EE-9EC7-51195C84E66B

\subsubsection{Type material}

Adult female holotype (USNM 1558501) collected on May 18, 2018 off Mazatlán, Sinaloa State, Mexico, eastern Pacific (L3): $23^{\circ} 05^{\prime} 30^{\prime \prime} \mathrm{N}, 106^{\circ} 17^{\prime} 45^{\prime \prime} \mathrm{W} ; 5 \mathrm{~m}$ depth; mounted in Fluoromount $G^{\circledR}$. Two adult male (USNM 1558502-1558503) and five adult female (USNM 1558504-1558508) paratypes with same collecting data as holotype; mounted in Fluoromount $\mathrm{G}^{\circledR}$.

\subsubsection{Diagnosis}

Cephalorhyncha with middorsal, acicular spines on segments 4, 6 and 8, in sublateral position on segment 7, and in lateroventral position on segments 8-9. Tubes present in subdorsal position on segment 2 and in lateroventral position on segment 5. Primary pectinate fringe of segments 2-7 with a tuft of elongated spinous projections in middorsal position, whereas straight and not elongated on the sternal plates. Cuticular hairs generally scarce, distributed in one or two straight rows only in the posterior half of the cuticular plates, absent on segments 1 and 11.

\subsubsection{Etymology}

The species is dedicated to the dear mother of the first author, who always encouraged and supported him in his biological research. 
493

494

495

496

497

498

499

500

501

502

503

504

505

506

507

508

509

510

511

512

513

514

515

516

517

518

519

520

521

522

523

524

\subsubsection{Description}

See Table 6 for measurements and dimensions, and Table 7 for summary of location of spines, tubes, nephridiopores, glandular cell outlets and sensory spots.

Head with retractable mouth cone and introvert (Fig. 11A-B, D-E). Although the holotype and two paratypes had the head partially everted, oral styles and scalids tended to collapse when mounted for LM. There were no available specimens for SEM examination, and only some details of these structures can be provided. Internal part of mouth cone with several rings of inner oral styles; exact number, morphology and arrangement of inner oral styles not determined. External part of mouth cone with a ring of 9 outer oral styles (Fig. 11D). Outer oral styles alternate between longer and shorter ones; five long styles appear anterior to the odd-numbered introvert sections, whereas four shorter ones appear anterior to the even-numbered introvert sections, except in the middorsal section 6 where a style is missing (Fig. 11D). Outer oral styles with two jointed subunits, with a rectangular, smooth basis and a triangular, hook-like, curved inwards, distal piece (Fig. 11D).

Introvert with several rings of cuticular scalids. Ring 01 with ten primary spinoscalids with of a short, quadrangular basal sheath and a distal, elongated end piece; distal piece thick, rounded in cross-section, smooth, hook-like (Fig. 11E). Remaining rings with several scalids also composed of two jointed subunits (Fig. 11E); detailed morphology and arrangement of these scalids not determined.

Neck with sixteen distinct, well-defined, trapezoidal placids, wider at base, with a marked joint between the neck and segment 1 (Figs. 10A-B and 11F-G); midventral one widest (ca. $7 \mu \mathrm{m}$ wide at base) (Figs. 10A and 11G), remaining ones similar in width (ca. $5 \mu \mathrm{m}$ wide at base) (Figs. 10A-B and 11F-G). Placids closely situated together at base, separated distally by cuticular folds (Figs. 10A-B and 11F-G). Six trichoscalids attach to the placids of the neck via small, oval trichoscalid plates (Figs. $10 \mathrm{~A}-\mathrm{B}$ and $11 \mathrm{~F}-\mathrm{G})$.

Trunk slender, markedly tapered towards hind end, composed of eleven trunk segments (Figs. 10A-B and 11A-B). Segment 1 as closed cuticular ring (Figs. 10A-B, $11 \mathrm{~A}-\mathrm{B}$ and 12A-B); segment 2 with one tergal and one sternal cuticular plate (Figs. 10A-B, 11A-B, H and 12A-B); remaining ones with one tergal and two sternal cuticular plates (Figs. 10A-B, 11A-B and 12A-F). Sternal plate of segment 2 incompletely 
525 subdivided by an indistinct midventral fissure (Fig. 11H); tergosternal joints well-

526 defined, but joint sites without posteriorly extending projections (Fig. 10A). Tergal

527 anterior plates slightly bulging middorsally; posterior ones more flattened, giving the

528 animal a tapering outline in lateral view. Sternal plates reach their maximum width at

529 segment 6, progressively tapering towards the last trunk segments (Figs. 10A and 11B).

530 Cuticular hairs scarce, distributed in one or two straight, transverse rows on each

531 segment at the posterior half of the cuticular plates, except on segments 1 and 11 where

532 cuticular hairs are absent (except those associated with the sensory spots) (Figs. 10A-B

533 and 12A-F); cuticular hairs relatively long, flexible, emerging from rounded perforation

534 sites (Figs. 12A-F). Most of sensory spots flanked by paired, elongated cuticular hairs

535 (Figs. 10A-B and 12A-F). Posterior margin of segments straight, with well-developed

536 primary pectinate fringes with conspicuously serrated free flaps (Figs. 10A-B and 12A-

537 F); primary pectinate fringes of segments 2-8 forming a middorsal tuft of long, spinous

538 projections (Figs. 10A-B and 12A, C). Secondary pectinate fringes well-developed,

539 slightly extending beyond the limit of the primary pectinate fringes (Figs. 10A-B and 540 12A-F).

541 Segment 1 without spines, tubes or cuticular hairs (except those associated with 542 the sensory spots). Unpaired type 1 glandular cell outlet in middorsal position, near the 543 anterior margin of segment (Figs. 10B and 12A). Paired sensory spots in subdorsal, 544 laterodorsal and lateroventral position, flanked by cuticular hairs, except the 545 lateroventral ones (Figs. 10A-B and 12A-B); detailed morphology of these and 546 remaining sensory spots not determined.

547 Segment 2 with paired large tubes in subdorsal position (Figs. 10B and 12A). 548 Unpaired type 1 glandular cell outlet in middorsal position near the anterior margin of 549 segment (Figs. 10B and 12A). Paired sensory spots in paradorsal and midlateral 550 positions, flanked by cuticular hairs (Figs. 10B and 12A).

551 Segment 3 without spines or tubes. Unpaired type 1 glandular cell outlet in 552 middorsal position, near the anterior margin of segment (Figs. 10B and 12A). Paired 553 sensory spots in paradorsal, subdorsal and sublateral positions, flanked by cuticular 554 hairs (Figs. 10A-B and 12A-B).

Segment 4 with a middorsal spine slightly exceeding the posterior edge of the 556 following segment (Figs. 10B and 12A). Paired sensory spots in paradorsal and 
557 sublateral positions, the former posterior to the base of the middorsal spine, both 558 laterally flanked by cuticular hairs (Figs. 10A-B and 12A-B). (Figs. 10A and 12D). Paired sensory spots in ventrolateral position, near the intersection

561 between the ventrolateral and the ventromedial regions, not flanked by cuticular hairs 562 (Figs. 10A and 12D).

Segment 6 with a middorsal acicular spine exceeding the posterior edge of the following segment, but not reaching the posterior margin of segment 8 (Figs. 10B and 12C). Paired sensory spots in paradorsal and ventrolateral regions, the former posterior to the base of the middorsal spine, the latter aligned with those of the previous segment, without lateral cuticular hairs (Figs. 10A-B and 12C-D).

Segment 7 with paired acicular spines in sublateral position, slightly exceeding the posterior edge of the following segment (Figs. 10A-B and 12D). Paired sensory spots in subdorsal position, flanked by cuticular hairs (Figs. 10B and 12C).

Segment 8 with a middorsal acicular spine exceeding the posterior edge of segment 10 but not reaching the posterior end of trunk, and paired acicular spines in lateroventral position, not reaching the posterior edge of the following segment (Figs. 10A-B and 12C-D). Paired sensory spots in paradorsal position, flanked by cuticular hairs (Figs. 10B and 12C).

Segment 9 with paired acicular spines in lateroventral position, slightly exceeding the posterior edge of the following segment (Figs. 10A and 12F). Unpaired type 1 glandular cell outlet in middorsal position, near the anterior margin of segment (Figs. 10B and 12E). Paired sensory spots in paradorsal and laterodorsal positions, flanked by cuticular hairs (Figs. 10B and 12E). Paired nephridiopores in midlateral position (Figs. 10A and 12F); detailed morphology of nephridiopores not determined.

Segment 10 without spines or tubes. Unpaired type 1 glandular cell outlet in middorsal position, near the anterior margin of segment (Figs. 10B and 12E). Paired sensory spots in subdorsal position near the posterior margin of segment, flanked by cuticular hairs (Figs. 10B and 12E). 
588

589

590

591

592

593

594

595

596

597

598

599

600

601

602

603

604

605

606

607

608

609

610

611

612

613

614

615

616

617

618

619

with three pairs of penile spines; one pair short, rigid and stubby, the other ones longer, pointed and much more flexible (Figs. 10C-D). Females with paired lateral terminal accessory spines, much shorter than lateral terminal ones (LTAS:LTS average ratio = $11.5 \%$ ) (Figs. 10A-B and 11C). Unpaired type 1 glandular cell outlet in middorsal position, near the anterior margin of segment (Figs. 10B, D and 12E). Paired sensory spots in paradorsal position, flanked by cuticular hairs, near the posterior margin of segment (Figs. 10B, D and 12E). Tergal plate with tergal extensions long and pointed distally (Figs. 10B, D and 12E). Sternal plates with rounded sternal extensions (Figs. $10 \mathrm{~A}, \mathrm{C}$ and $12 \mathrm{~F})$.

\subsubsection{Remarks on differential characters}

Cephalorhyncha teresae sp. nov. agrees well with the diagnosis of the genus (Adrianov and Malakhov, 1999; Neuhaus and Blasche, 2006). With the description of the new species, the genus is currently composed of six species: $C$. asiatica (Adrianov, 1989), $C$. liticola Sørensen, 2008, C. flosculosa Yildiz et al., 2016, C. nybakkeni (Higgins, 1986), a newly described species from Pacific polymetallic nodules (see Sánchez et al., this issue), and C. teresae sp. nov. The former five species are characterized by having middorsal, acicular spines on segments $4-8$ as well as lateral spines and/or tubes on segments 5-9. Cephalorhyncha teresae sp. nov. possesses middorsal, acicular spines only on segments 4, 6 and 8, and lateral spines on segments 8-9 only. Additionally, the five known species share the presence of paired ventrolateral spines or tubes on segment 2, while $C$. teresae sp. nov. has paired tubes in subdorsal position on this segment. Moreover, $C$. teresae sp. nov. is unique among its congeners in the sublateral position of the spines of segment 6 .

Regarding the trunk habitus, C. teresae sp. nov. is more similar to C. asiatica, with a body outline closer to that of the genus Echinoderes, whereas $C$. nybakkeni is a slender species more similar to some species of Meristoderes, and C. flosculosa and $C$. liticola are characterized by having laterally compressed bodies.

Furthermore, most species of the genus have midventral tufts of elongated, spinous extensions belonging to the primary pectinate fringes on most of the trunk segments, which are absent in the newly described species. However, C. teresae sp. nov. is unique also in the middorsal position of these tufts of elongated spinous elongations on segments $2-7$. 
621 Genus Echinoderes Claparède, 1863

622 3.4 Echinoderes xalkutaat sp. nov.

623 (Figs. 13-16 and Tables 8-9)

624 urn:1sid:zoobank.org:act:112843D9-15DE-4013-9C00-C2B2445BD537

625 3.4.1 Type material

626 Adult female holotype (USNM 1558509) collected on February 11, 2007 at the central

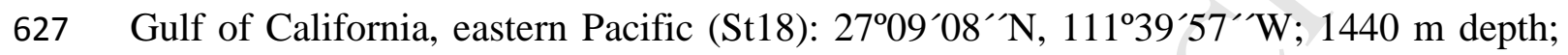

628 mounted in Fluoromount G®. Two adult female paratypes (USNM 1558510-1558511)

629 with same collecting data as holotype; mounted in Fluoromount G®.

630 3.4.2 Diagnosis

631 Echinoderes with middorsal spines on segments 4-8, lateroventral spines on segments 632 6-9, and lateroventral tubes on segment 5. Type 2 glandular cell outlets present in 633 subdorsal, laterodorsal, sublateral and ventrolateral positions on segment 2, in 634 midlateral position on segment 5 , in sublateral position on segment 8 and laterodorsal 635 position in segment 10. Segment 11 composed of one tergal and two sternal plates, 636 lacking cuticular hairs but with short, tiny hair-like extensions in paradorsal position.

637 3.4.3 Etymology

638 The species is named after the myth of the monster "Xalkutaat" of the Paipai people of 639 Santa Catarina, Baja California. According to the legend, Xalkutaat would be a dragon640 like creature endowed with fire faced and defeated by a child called "Pies Ligeros" 641 (meaning Light Feet), who gave fire to humanity.

642

643

\subsubsection{Description}

See Table 8 for measurements and dimensions, and Table 9 for summary of the location of spines, tubes, nephridiopores, glandular cell outlets and sensory spots.

Head with retractable mouth cone and introvert (Fig. 14B-D). Although one of the paratypes had the introvert partially everted, oral styles and scalids tended to collapse when mounted for LM. There were no available specimens for SEM examination, and only some details of these structures can be provided. Internal part of 
mouth cone with several rings of inner oral styles; exact number, arrangement and morphology of inner oral styles not determined. External part of mouth cone with 9 outer oral styles. Outer oral styles alternate between slightly longer and slightly shorter ones (Fig. 14B); five long styles appear anterior to the odd-numbered introvert sections, whereas four sligthly shorter ones appear anterior to the even-numbered introvert sections, except in the middorsal section 6 where a style is missing. Outer oral styles with two jointed subunits, with rectangular basis bearing a short, medial fringe, and a triangular, hook-like, distal structure (Fig. 14B).

Introvert with several rings of scalids. Ring 01 with ten primary spinoscalids with a short, rectangular basal sheath and a distal, long end piece; distal piece wide, rounded to oval in cross-section, smooth, hook-like, with blunt tip (Fig. 14C). Remaining rings with several scalids also composed of two jointed subunits (Fig. 14D); detailed morphology and arrangement of these scalids not determined.

Neck with sixteen trapezoidal placids, wider at base, with a distinct joint between the neck and segment 1 (Figs. 13A-B and 14E); midventral one widest (ca. 12 $\mu \mathrm{m}$ wide at base) (Figs. 13A and 14E), remaining ones alternate between wider and narrower (6-8 $\mu \mathrm{m}$ wide at base) (Figs. 13A-B and 14E). Placids situated closely together at base, separated distally by cuticular folds (Figs. 13A-B and 14E). Six hairy trichoscalids attach to small, longitudinally compressed trichoscalid plates (Figs. 13A-B and 14E).

Trunk markedly slender, distally tapered, composed of eleven trunk segments (Figs. 13A-B and 14A). Segments $1-2$ as closed cuticular rings; remaining ones with one tergal and two sternal plates (Figs. 13A-B, 14A, 15A-J and 16A-H). Tergal anterior plates slightly bulging middorsally; posterior ones more flattened, giving the animal a tapering outline in lateral view (Fig. 14A). Sternal plates reach their maximum width at segment 7, progressively tapering towards the last trunk segments (Figs. 13A and 14A). Cuticular hairs densely distributed all over the trunk in irregular, transverse rows increasing in number towards the posterior end of trunk, plus unpaired midventral patches, except the mesial half of sternal plates of segments 3-10, the anterior half of segment 10 and all of segment 11 where cuticular hairs are absent (Figs. 13A-B, 14A, 15A-J and 16A-H). Posterior margin of segments straight, with well-developed primary pectinate fringes that possess elongated, strongly serrated free flaps; secondary pectinate fringes not detected with LM (Fig. 13A-B). 
Segment 1 without spines or tubes. Unpaired type 1 glandular cell outlet in

683

684

685

686

687

688

689

690

691

692

693

694

695

696

697

698

699

700

701

702

703

704

705

706

707

708

709

710

711

712

713 middorsal position (Figs. 13B and 15A). Paired sensory spots in subdorsal, laterodorsal, sublateral and ventrolateral positions (Figs. 13A-B and 15A-B).

Segment 2 without spines or tubes. Unpaired type 1 glandular cell outlet in middorsal position (Figs. 13B and 15C), and paired in ventromedial position (Figs. 13A and 15D). Paired type 2 glandular cell outlets in subdorsal, laterodorsal, sublateral and ventrolateral positions; type 2 glandular cell outlets on this and remaining segments flanked by lateral marginal elongated cuticular hairs (Figs. 13A-B and 15C-D). Unpaired sensory spot in middorsal position, posterior to the middorsal type 1 glandular cell outlet (Figs. 13B and 15C); paired sensory spots in ventromedial position, lateral to the ventromedial type 1 glandular cell outlets, not aligned with those of following segments (Figs. 13A and 15D).

Segment 3 without spines or tubes. Unpaired type 1 glandular cell outlet in middorsal position (Figs. 13B and 15E), and paired in ventromedial position (Figs. 13A and $15 \mathrm{~F}$ ). Paired sensory spots in laterodorsal and ventromedial positions, the latter mesial and posterior to the ventromedial type 1 glandular cell outlets (Figs. 13A-B and $15 \mathrm{E}-\mathrm{F})$.

Segment 4 with a middorsal spine exceeding the posterior edge of the following segment (Figs. 13B and 15G). Paired type 1 glandular cell outlets in paradorsal and ventromedial regions (Figs. 13A-B and 15G-H). Paired sensory spots in laterodorsal position (Figs. 13B and 15G).

Segment 5 with a middorsal spine exceeding the posterior edge of the following segment, but not reaching the posterior margin of segment 7 (Figs. 13B and 15I), and paired, short, narrow tubes in lateroventral position (Figs. 13A and 15J). Paired type 1 glandular cell outlets in paradorsal and ventromedial positions (Figs. 13A-B and 15I-J). Paired type 2 glandular cell outlets in midlateral position (Figs. 13B and 15I). Paired sensory spots in laterodorsal and ventromedial positions, the midlateral pair immediately next to the midlateral type 2 glandular cell outlets and the ventromedial pair posterior to the type 1 glandular cell outlets (Figs. 13A-B and 15I-J).

Segment 6 with a middorsal spine exceeding the posterior edge of the following segment but not reaching the posterior margin of segment 8 , and paired spines in lateroventral position (Figs. 13A-B and 16A-B). Paired type 1 glandular cell outlets in 
714 paradorsal and ventromedial positions (Figs. 13A-B and 16A-B). Paired sensory spots

715 in paradorsal, subdorsal, laterodorsal, midlateral and ventromedial positions, the

716 paradorsal pair posterior to the paradorsal type 1 glandular cell outlets and the

717 ventromedial pair posterior to the type 1 glandular cell outlets (Figs. 13A-B and 16A718 B).

719

720

721

722

723

724

725

726

727

728

729

730

731

732

733

734

735

736

737

738

739

740

741

742

743

744

Segment 7 with a middorsal spine exceeding the posterior edge of the following segment but not reaching the posterior margin of segment 9, and paired spines in lateroventral position longer than those of preceding segments (Figs. 13A-B and 16BC). Paired type 1 glandular cell outlets in paradorsal and ventromedial positions (Figs. 13A-B and 16B-C). Paired sensory spots in paradorsal, laterodorsal, midlateral and ventromedial positions, the paradorsal pair posterior to the paradorsal type 1 glandular cell outlets, the ventromedial pair posterior to the ventromedial type 1 glandular cell outlets (Figs. 13A-B and 16B-C).

Segment 8 with a middorsal spine exceeding the posterior edge of segment 10 but not reaching the posterior end of trunk, and paired spines in lateroventral position longer than those of the preceding segment (Figs. 13A-B and 16B, D). Paired type 1 glandular cell outlets in paradorsal and ventromedial positions (Figs. 13A-B and 16B, D). Paired type 2 glandular cell outlets in sublateral position (Figs. 13A and 16D). Paired sensory spots in paradorsal position, posterior to the paradorsal type 1 glandular cell outlets (Figs. 13B and 16D).

Segment 9 with paired spines in lateroventral position, shorter than those of the preceding segment (Figs. 13A and 16F). Paired type 1 glandular cell outlets in paradorsal and ventromedial positions (Figs. 13A-B and 16E-F). Paired sensory spots in paradorsal, subdorsal, midlateral, sublateral and ventromedial positions (Figs. 13A-B and 16E-F). Nephridiopore as a very small sieve plate, in lateral accessory position (Figs. 13A and 16F).

Segment 10 without spines or tubes. Two unpaired type 1 glandular cell outlets in middorsal position (Figs. 13B and 16G), and paired in ventromedial position (Figs. $13 \mathrm{~A}$ and $16 \mathrm{H}$ ). Paired type 2 glandular cell outlets in laterodorsal position, near the posterior margin of segment (Figs. 13B and 16G). Paired sensory spots in subdorsal position (Figs. 13B and 16G). 
Segment 11 with lateral terminal spines long (LTS:TL average ratio $=60.6 \%$ ),

746 slender, flexible, pointed distally, with a central cavity (Figs. 13A-B and 14A). Females

747 with paired lateral accessory terminal spines, shorter than lateral terminal ones

748 (LTAS:LTS average ratio = 18.3\%) (Figs. 13A-B and 14A). Unpaired type 1 glandular 749 cell outlet in middorsal position (Figs. 13B and 16G). Paired sensory spots in paradorsal 750 position (Figs. 13B and 16G). Tergal plate of females with small patches bearing short, 751 tiny hair-like extensions in paradorsal position (Fig. 13B). Tergal extensions long, 752 pointed distally; sternal plates distally rounded (Figs. 13A-B and 16I).

\subsubsection{Remarks on differential characters}

Echinoderes xalkutaat sp. nov. is characterized by possessing middorsal spines on segments 4-8, lateroventral spines on segments 6-9, lateroventral tubes on segment 5, four pairs of type 2 glandular cell outlets on segment 2 and one pair on segments 5,8 and 10. The general arrangement of spines and tubes in E. xalkutaat sp. nov. is one of the most common patterns among species of the genus (Grzelak and Sørensen, 2018; Neuhaus, 2013; Sørensen and Pardos, 2008), but the presence of several pairs of type 2 glandular cell outlets throughout segments 2, 5,8 and 10 is not as common.

The presence of four pairs of type 2 glandular cell outlets in subdorsal, laterodorsal, sublateral and ventrolateral positions on segment 2, together with the aforementioned arrangement of spines and tubes, is only shared with seven congeners: E. angustus Higgins and Kristensen, 1988, E. cernunnos Sørensen et al. 2012, E. drogoni Grzelak and Sørensen, 2018, E. juliae Sørensen et al. 2018, E. obtuspinosus Sørensen et al., 2012, E. romanoi Landers and Sørensen, 2016 and E. tubilak Higgins and Kristensen, 1988. However, the new species possesses paired type 2 glandular cell outlets in midlateral position on segment 5 , in sublateral position on segment 8 , and in laterodorsal position on segment 10 . This combination is only shared with E. angustus and E. drogoni, whereas Echinoderes cernunnos bears these structures on segments 5 and 7-8, E. juliae on segments 3-5 and 8, E. obtuspinosus on segments 4 and 8, E. romanoi on segments 5 and 8 and E. tubilak on segments 4-5 and 8 (Grzelak and Sørensen, 2018; Landers and Sørensen, 2016; Sørensen et al. 2012; 2018). Echinoderes angustus can be distinguished from the new species by its type 2 glandular cell outlets on segment 4, and $E$. drogoni has the tubes of segment 5 displaced to a lateral accessory position (Grzelak and Sørensen, 2018). Additionally, the female of E. drogoni has two 
777 tergal plates on segment 11 (Grzelak and Sørensen, 2018), while that of E. xalkutaat sp.

778 nov. possesses only a single tergal plate on segment 11.

779

780 4. References

781 Adrianov, A.V., 1989. The first report on Kinorhyncha of the Sea of Japan. Zool. Zh. 782 68(7), 17-27.

783 Adrianov, A.V., Malakhov, V.V., 1999. Cephalorhyncha of the world ocean. KMK 784 Scientific Press, Moscow.

785 Álvarez-Castillo, L., Hermoso-Salazar, M., Estradas-Romero, A., Prol-Ledesma, R.M., 786 Pardos, F., 2015. First records of Kinorhyncha from the Gulf of California: horizontal 787 and vertical distribution of four genera in shallow basins with $\mathrm{CO}_{2}$ venting activity. 788 Cah. Biol. Mar. 56(3), 271-281.

789 Álvarez-Castillo, L., Hermoso-Salazar, M., Estradas-Romero, A., Prol-Ledesma, R.M., 790 Pardos, F., 2018. New record of Fissuroderes thermoi (Kinorhyncha: Cyclorhagida) in 791 the Gulf of California. Cah. Biol. Mar. 59, 235-244.

792 Appeltans, W., Ahyong, S.T., Anderson, G., Angel, M.V., Artois, T., Bailly, N., et al., 793 2012. The magnitude of global marine species diversity. Curr. Biol. 22, 2189-2202. 794 https://doi.org/10. 1016/j.cub.2012.09.036.

795 Cepeda, D., Pardos, F., Sánchez, N., this issue. Kinorhyncha from the Caribbean, with 796 the description of two new species from Puerto Rico and Barbados. Zool. Anz., this 797 issue.

798 Claparède, A.R.E., 1863. Zur Kenntnis der Gattung Echinoderes Duj. Beobachtungen 799 über Anatomie und Entwicklungsgeschichte wirbelloser Thiere an der Küste von 800 Normandie angestellt. Verlag von Wilhelm Engelmann, Leipzig.

801 Gerlach, S.A., 1971. On the importance of marine meiofauna for benthos communities. 802 Oecologia 6, 176-190.

803 Grzelak, K., Sørensen, M.V., 2018. New species of Echinoderes (Kinorhyncha: 804 Cyclorhagida) from Spitsbergen, with additional information about known Arctic 805 species. Mar. Biol. Res. 14, 113-147. https:/doi.org/10.1080/17451000.2017.1367096. 
806 Hakenkamp, C.C., Morin, A., 2001. The importance of meiofauna to lotic ecosystem

807 functioning. Freshwater Biol. 44, 165-175. https://doi.org/10.1046/j.1365-

$808 \quad 2427.2000 .00589 . x$.

809 Higgins, R.P., 1961. Three new homalorhage kinorhynchs from the San Juan

810 Archipelago, Washington. J. Elisha Mitchell Sci. Soc. 77(1), 81-88.

811 Higgins, R.P., 1964. Three new kinorhynchs from the North Carolina Coast. Bull. Mar.

812 Sci. 14, 479-493.

813 Higgins, R.P., 1983. The Atlantic barrier reef ecosystem at Carrie Bow Cay, Belize, II:

814 Kinorhyncha. Smithson. Contrib. Mar. Sci. 18, 1-131.

815 https://doi.org/10.5479/si.01960768.18.1.

816 Higgins, R.P., 1986. A new species of Echinoderes (Kinorhyncha: Cyclorhagida) from 817 a coarse-sand California beach. Trans. Am. Microsc. Soc. 105, 266-273. https://doi.org/ $818 \quad 10.2307 / 3226298$.

819 Higgins, R.P., Kristensen, R.M., 1988. Kinorhyncha from Disko Island, West 820 Greenland. Smithson. Contrib. Zool. 458, 1-55. 821 https://doi.org/10.5479/si.00810282.458.

822 Landers, S.C., Sørensen, M.V., 2016. Two new species of Echinoderes (Kinorhyncha, 823 Cyclorhagida), E. romanoi sp n. and E. joyceae sp n., from the Gulf of Mexico. 824 ZooKeys 594, 51-71. https://doi.org/10.3897/zookeys.594.8623.

825 Lang, K., 1953. Reports of the Lund University Chile Expedition 1948-1949. 9. 826 Echinoderida. Lunds Universitets Årsskrift N. F. Avd. 2 49, 3-8.

827 Mokievsky, V., Azovsky, A., 2002. Re-evaluation of species diversity patterns of free828 living marine nematodes. Mar. Ecol. Prog.Ser. 238, 101-108. https://doi.org/10.3354/ 829 meps 238101.

830 Neuhaus, B., 2013. Kinorhyncha (=Echinodera), in: Schmidt-Rhaesa, A. (Ed.), 831 Handbook of Zoology, Gastrotricha, Cycloneuralia and Gnathifera, Volume 1 832 Nematomorpha, Priapulida, Kinorhyncha, Loricifera. De Gruyter, Hamburg, pp. 181833350.

834 Neuhaus, B., Blasche, T., 2006. Fissuroderes, a new genus of Kinorhyncha 835 (Cyclorhagida) from the deep sea and continental shelf of New Zealand and from the 
836 continental shelf of Costa Rica. Zool. Anz. 245, 19-52.

837 https://doi.org/10.1016/j.jcz.2006.03.003.

838 Sánchez, N., Pardos, F., Herranz, M., Benito, J., 2011. Pycnophyes dolichurus sp. nov. 839 and $P$. aulacodes sp. nov. (Kinorhyncha, Homalorhagida, Pycnophyidae), two new 840 kinorhynchs from Spain with a reevaluation of homalorhagid taxonomic characters. 841 Helgol. Mar. Res. 65, 319-334. https://doi.org/10.1007/s10152-010-0226-z.

842 Sánchez, N., Pardos, F., Martínez-Arbizu, P., this issue. Deep-sea Kinorhyncha 843 diversity of the polymetallic nodule fields at the Clarion-Clipperton Fracture Zone 844 (CCZ). Zool. Anz., this issue.

845 Sánchez, N., Pardos, F., Sørensen, M.V., 2014. Deep-sea Kinorhyncha: two new species 846 from the Guinea Basin, with evaluation of an unusual male feature. Org. Divers. Evol. 847 14(4), 349-361. https://doi.org/10.1007/s13127-014-0182-6.

848 Sánchez, N., Yamasaki, H., Pardos, F., Sørensen, M.V., Martínez, A., 2016. 849 Morphology disentangles the systematics of a ubiquitous but elusive meiofaunal group 850 (Kinorhyncha: Pycnophyidae). Cladistics 379-505. 851 https://doi.org/10.1111/cla.12143.

852 Schmid-Araya, J.M., Hildrew, A.G., Robertson, A., Schmid, P.E., Winterbottom, J., 853 2002. The importance of meiofauna in food webs: evidence from an acid stream. 854 Ecology 83(5), 1271-1285. https://doi.org/10.2307/3071942.

855 Schratzberger, M., Ingels, J., 2017. Meiofauna matters: the roles of meiofauna in 856 benthic ecosystems. J. Exp. Mar. Biol. Ecol. 502, 12-25. 857 https://doi.org/10.1016/j.jembe.2017.01.007.

858 Sørensen, M.V., 2008. A new kinorhynch genus from the Antarctic deep sea and a new 859 species of Cephalorhyncha from Hawaii (Kinorhyncha: Cyclorhagida: Echinoderidae). 860 Org. Divers. Evol. 8, 230-232. https://doi.org/10.1016/j.ode.2007.11.003.

861 Sørensen, M.V., Dal Zotto, M., Rho, H.S., Herranz, M., Sánchez, N., Pardos, F., 862 Yamasaki, H., 2015. Phylogeny of Kinorhyncha based on morphology and two 863 molecular loci. PLoS ONE 10(7), e0133440. 864 https://doi.org/10.1371/journal.pone.0133440. 
865 Sørensen, M.V., Pardos, F., 2008. Kinorhynch systematics and biology - An 866 introduction to the study of kinorhynchs, inclusive identification keys to the genera. 867 Meiofauna Marina 16, 21-73.

868 Sørensen, M.V., Rho, H.S., Min, W.G., Kim, D., Chang, C.Y., 2012. An exploration of 869 Echinoderes (Kinorhyncha: Cyclorhagida) in Korean and neighboring waters, with the 870 description of four new species and a redescription of E. tchefouensis Lou, 1934. 871 Zootaxa 3368, 161-196.

872 Sørensen, M.V., Rohal, M., Thistle, D., 2018. Deep-sea Echinoderidae (Kinorhyncha: 873 Cyclorhagida) from the Northwest Pacific. Eur. J. Taxon. 456, 1-75. 874 https://doi.org/10.5852/ejt.2018.456.

875 Yildiz, N.O., Sørensen, M.V., Karaytug, S., 2016. A new species of Cephalorhyncha 876 Adrianov, 1999 (Kinorhyncha: Cyclorhagida) from the Aegean Coast of Turkey. 877 Helgol. Mar. Res. 70, 24. https://doi.org/10.1186/s10152-016-0476-5.

878 Zelinka, C., 1894. Über die Organisation von Echinoderes. Verh. Dtsch. Zool. Ges. 4, $87946-49$.

880 Zelinka, C., 1896. Demonstration der Tafeln der Echinoderes - Monographie. Verh. 881 Dtsch. Zool. Ges. 6, 197-199.

882

\section{FUNDING SOURCES}

884 The present study was partially funded by the projects IN-217306-3 and IN-202116, by 885 Programa de Apoyo a Proyectos de Investigación e Innovación Tecnológica (PAPIIT) 886 of Dirección General de Asuntos del Personal Académico (DGAPA); and the project 887 BIO03/2017, granted by Unión Iberoamericana de Universidades (UIU). Complutense de Madrid UCM (CT27/16-CT28-16).

893 Table 1. Data on sampling, localities and collected species. 
ACCEPTED MANUSCRIPT

\begin{tabular}{|c|c|c|c|c|c|c|}
\hline Location & $\begin{array}{l}\text { Geographical } \\
\text { coordinates }\end{array}$ & $\begin{array}{l}\text { Sampling } \\
\text { date }\end{array}$ & Habitat & $\begin{array}{l}\text { Depth } \\
\text { (m) }\end{array}$ & $\begin{array}{l}\text { Sampling } \\
\text { method }\end{array}$ & Collected species \\
\hline $\begin{array}{l}\text { Central Gulf of } \\
\text { California (St15) }\end{array}$ & $\begin{array}{l}27^{\circ} 42^{\prime} 00^{\prime \prime} \mathrm{N} \\
111^{\circ} 38^{\prime} 00^{\prime} \mathrm{W}\end{array}$ & $11 / 02 / 2007$ & Mud & 1570 & Box corer & $\begin{array}{l}\text { Cristaphyes fortis } \\
\text { sp.nov. }\end{array}$ \\
\hline $\begin{array}{l}\text { Central Gulf of } \\
\text { California (St18) }\end{array}$ & $\begin{array}{l}27^{\circ} 09^{\prime} 08^{\prime \prime} \mathrm{N} \\
111^{\circ} 39^{\prime} 57^{\prime} \mathrm{W}\end{array}$ & $11 / 02 / 2007$ & Mud & 1440 & Box corer & $\begin{array}{l}\text { Cristaphyes fortis } \\
\text { sp.nov.; Echinoderes } \\
\text { xalkutaat sp. nov. }\end{array}$ \\
\hline $\begin{array}{l}\text { South of } \\
\text { Mazatlán (L3) }\end{array}$ & $\begin{array}{l}23^{\circ} 05^{\prime} 30^{\prime \prime} \mathrm{N} \\
106^{\circ} 17^{\prime} 45^{\prime} \mathrm{W}\end{array}$ & $18 / 05 / 2018$ & $\begin{array}{l}\text { Sandy } \\
\text { mud }\end{array}$ & 5 & $\begin{array}{l}\text { Meiobenthic } \\
\text { dredge }\end{array}$ & $\begin{array}{l}\text { Cephalorhyncha } \\
\text { teresae sp. nov.; } \\
\text { Higginsium }\end{array}$ \\
\hline
\end{tabular}

894

895 Table 2. Measurements of adult Cristaphyes fortis sp. nov. from the lower Gulf of 896 California, including number of measured specimens $(n)$, mean of data and standard 897 deviation (SD). There were no remarkable differences in size and/or dimension between 898 the two sexes or sampling locations. Abbreviations: LTS, lateral terminal spine; MSW8995 , maximum sternal width (on segment 5); S, segment lengths; SW-10, standard sternal 900 width (on segment 10); TL, total length of trunk.

\begin{tabular}{lll}
\hline Character & Range & Mean $($ SD; $\boldsymbol{n})$ \\
\hline TL $(\mu \mathrm{m})$ & $618.8-664.6$ & $644.5(19.6 ; 4)$ \\
MSW-5 $(\mu \mathrm{m})$ & $151.6-171.2$ & $159.9(8.4 ; 4)$ \\
MSW-5/TL $(\%)$ & $23.9-26.7$ & $24.8(1.3 ; 4)$ \\
SW-10 $(\mu \mathrm{m})$ & $120.6-134.4$ & $128.8(5.9 ; 4)$ \\
SW-10/TL $(\%)$ & $19.5-21.0$ & $20.0(0.7 ; 4)$ \\
S1 $(\mu \mathrm{m})$ & $94.4-113.3$ & $101.7(8.5 ; 4)$ \\
S2 $(\mu \mathrm{m})$ & $54.3-67.3$ & $60.8(7.2 ; 4)$ \\
S3 $(\mu \mathrm{m})$ & $56.3-78.5$ & $65.9(9.4 ; 4)$ \\
S4 $(\mu \mathrm{m})$ & $62.6-68.0$ & $65.2(2.4 ; 4)$ \\
S5 $(\mu \mathrm{m})$ & $57.1-75.0$ & $67.5(7.7 ; 4)$ \\
S6 $(\mu \mathrm{m})$ & $65.3-86.6$ & $72.7(9.5 ; 4)$ \\
S7 $(\mu \mathrm{m})$ & $61.0-77.6$ & $71.2(7.1 ; 4)$ \\
S8 $(\mu \mathrm{m})$ & $56.7-83.6$ & $69.6(11.0 ; 4)$ \\
S9 $(\mu \mathrm{m})$ & $69.5-81.5$ & $73.9(5.5 ; 4)$ \\
S10 $(\mu \mathrm{m})$ & $76.2-86.9$ & $81.3(5.1 ; 4)$ \\
S11 $(\mu \mathrm{m})$ & $35.0-40.1$ & $37.1(2.3 ; 4)$ \\
LTS $(\mu \mathrm{m})$ & $173.6-197.4$ & $186.5(9.9 ; 4)$ \\
LTS/TL $(\%)$ & $26.6-30.0$ & $29.0(1.6 ; 4)$ \\
\end{tabular}


901

902 Table 3. Summary of nature and arrangement of sensory spots, glandular cell outlets,

903 cuticular processes, setae, nephridiopores and spines in adults of Cristaphyes fortis sp.

904 nov. Abbreviations: cp, cuticular process; gco, glandular cell outlet; LD, laterodorsal;

905 lts, lateral terminal spine; LV, lateroventral; m, male condition of sexually dimorphic

906 character; MD, middorsal; ne, nephridiopore; PD, paradorsal; PL, paralateral; ps, penile

907 spine; SD, subdorsal; se, seta; ss, sensory spot; ss3, type 3 sensory spot; VL,

908 ventrolateral; VM, ventromedial; * indicates intraspecific variation, and that structure

909 may be paired, unpaired or absent; ${ }^{\wedge}$ indicates the presence of unpaired structures.

\begin{tabular}{|c|c|c|c|c|c|c|c|c|}
\hline Segment & MD & PD & SD & LD & PL & $\mathbf{L V}$ & VL & VM \\
\hline 1 & & & gco & SS & se & & ss, gco & \\
\hline 2 & $\mathrm{cp}$ & $\mathrm{se}^{\boldsymbol{\Lambda}}$ & gco, ssx2 & gco, se, ss & & se & se, gco & $\operatorname{ssx} 2$, gco \\
\hline 3 & $\mathrm{cp}$ & & gco, ss & gco, se, ss & & & se, gco & ss, gco \\
\hline 4 & $\mathrm{cp}$ & $\mathrm{se}^{\boldsymbol{\Lambda}}$ & gco, ss & gco, se, ss & & se & se, gco & ss, gco \\
\hline 5 & $\mathrm{cp}$ & & gco, ss & gco, se*, ss & & & $\operatorname{sex} 2, \mathrm{gco}$ & ss, gco \\
\hline 6 & $\mathrm{cp}$ & $\mathrm{se}^{\wedge}$ & gco, ss & $\mathrm{gco}, \mathrm{se}^{*}, \mathrm{ss}$ & & & se, gco & ss, gco \\
\hline 7 & $\mathrm{cp}$ & & gco, ss & $\mathrm{gco}, \mathrm{se}^{*}, \mathrm{ss}$ & & & se, gco & Ss, gco \\
\hline 8 & $\mathrm{cp}$ & & gco, ss & gco, se, & & se & gco & ss, se, gco \\
\hline 9 & $\mathrm{cp}$ & & gco, ss & $\mathrm{gco}, \mathrm{se}^{*}, \mathrm{ss}$ & ne & & gco & ss, se, gco \\
\hline 10 & $\mathrm{cp}$ & & gco, ss & gco, ss & & $\mathrm{se}$ & se, gco & gco \\
\hline 11 & & & ss3 & & & lts, & & \\
\hline
\end{tabular}

910

911 Table 4. Measurements of adult Higginsium mazatlanensis sp. nov. from Mazatlán,

912 including number of measured specimens $(n)$, mean of data and standard deviation

913 (SD). There were no remarkable differences in size and/or dimension between the two

914 sexes or sampling locations. Abbreviations: MSW-6, maximum sternal width (on

915 segment 6); S, segment lengths; SW-10, standard sternal width (on segment 10); TL,

916 total length of trunk.

\begin{tabular}{lll}
\hline Character & Range & Mean $($ SD; $\boldsymbol{n})$ \\
\hline TL $(\mu \mathrm{m})$ & $527.7-581.5$ & $563.9(25.1 ; 4)$ \\
MSW-6 $(\mu \mathrm{m})$ & $107.5-151.6$ & $133.9(18.9 ; 4)$ \\
MSW-6/TL $(\%)$ & $19.0-26.7$ & $23.8(3.5 ; 4)$ \\
SW-10 $(\mu \mathrm{m})$ & $90.5-104.6$ & $96.7(7.2 ; 4)$ \\
SW-10/TL $(\%)$ & $16.0-18.0$ & $17.1(0.9 ; 4)$ \\
S1 $(\mu \mathrm{m})$ & $60.7-87.9$ & $76.0(11.3 ; 4)$
\end{tabular}




$\begin{array}{lll}\text { S2 }(\mu \mathrm{m}) & 52.0-57.6 & 52.6(6.1 ; 4) \\ \text { S3 }(\mu \mathrm{m}) & 48.4-56.6 & 54.2(5.7 ; 4) \\ \text { S4 }(\mu \mathrm{m}) & 53.0-61.4 & 58.1(3.7 ; 4) \\ \text { S5 }(\mu \mathrm{m}) & 57.1-64.3 & 59.2(3.4 ; 4) \\ \text { S6 }(\mu \mathrm{m}) & 65.4-76.4 & 68.8(5.2 ; 4) \\ \text { S7 }(\mu \mathrm{m}) & 62.9-73.1 & 68.7(4.3 ; 4) \\ \text { S8 }(\mu \mathrm{m}) & 60.3-84.6 & 73.3(11.2 ; 4) \\ \text { S9 }(\mu \mathrm{m}) & 71.4-74.9 & 73.6(1.6 ; 4) \\ \text { S10 }(\mu \mathrm{m}) & 39.2-52.7 & 43.5(6.2 ; 4) \\ \text { S11 }(\mu \mathrm{m}) & 18.7-26.6 & 22.8(3.8 ; 4)\end{array}$

917

918 Table 5. Summary of nature and arrangement of sensory spots, glandular cell outlets,

919 cuticular processes, cuticular elevations, setae, tubes, nephridiopores and spines in

920 adults of Higginsium mazatlanensis sp. nov. Abbreviations: ce, cuticular elevation; cp,

921 cuticular process; cpr, cuticular projection; gco, glandular cell outlet; LD, laterodorsal;

$922 \mathrm{LV}$, lateroventral; $\mathrm{m}$, male condition of sexually dimorphic feature; MD, middorsal; ne,

923 nephridiopore; PD, paradorsal; PL, paralateral; ps, penile spine; SD, subdorsal; se, seta;

924 ss, sensory spot; ss3, type 3 sensory spot; tu, tube; VL, ventrolateral; VM, ventromedial;

$925 \Delta$ indicates the presence of unpaired structures.

\begin{tabular}{|c|c|c|c|c|c|c|c|c|}
\hline Segment & MD & PD & SD & LD & $\mathbf{P L}$ & $\mathbf{L V}$ & VL & VM \\
\hline 1 & ce & ss & gco, se, ssx 2 & ss & se & ss & se, ss, gco & \\
\hline 2 & ce & se, ss & & gco, sex2, ss & & $\mathrm{se}$ & se, ss, gco & se, gco, tu (m) \\
\hline 3 & ce & $\mathrm{se}^{\mathbf{\Lambda}}$, & & gco, sex2, ss & & & se, gco & se, ss, gco \\
\hline 4 & ce & se, ss & gco, ssx 2 & gco, sex 2, ss & & se & se, gco & se, ss, gco \\
\hline 5 & ce & $\mathrm{se}^{\mathbf{\Lambda}}$, & gco, ssx 2 & gco, sex 2, ss & & & $\operatorname{sex} 2$, gco & se, ss, gco \\
\hline 6 & ce & se, ss & gco, ssx2 & gco, sex2, ss & & se & se, gco & se, ss, gco \\
\hline 7 & $\mathrm{cp}$ & $\mathrm{se}^{\mathbf{4}}$ & gco, ssx 2 & gco, sex $2, \mathrm{ss}$ & & & se, gco & se, ss, gco \\
\hline 8 & $\mathrm{cp}$ & se, ss & gco, ssx 3 & $\operatorname{sex} 2$, ss & & se & se, gco & se, ss, gco \\
\hline 9 & $\mathrm{cp}$ & $\mathrm{se}^{\mathbf{4}}$, & gco, ssx3 & $\operatorname{sex} 2, \mathrm{ss}$ & ne & & se, gco & se, ss, gco \\
\hline & & ss & & & & & & \\
\hline 10 & ce & $\mathrm{se}^{\boldsymbol{\Lambda}}$ & gco, ss & ss & & $\operatorname{sex} 2$ & gco & ss, gco \\
\hline 11 & & & ss3 & & & psx2 & & \\
\hline
\end{tabular}


927 Table 6. Measurements of adult Cephalorhyncha teresae sp. nov. from Mazatlán, 928 including number of measured specimens $(n)$, mean of data and standard deviation. 929 Remarkable differences in size and/or dimension between the two sexes were not 930 detected. Abbreviations: ac, acicular spine; LTAS, lateral terminal accessory spine; 931 LTS, lateral terminal spine; LV, lateroventral; MD, middorsal; MSW-6, maximum 932 sternal width (on segment 6); S, segment lengths; SD, subdorsal; SL, sublateral; SW-10, 933 standard sternal width (on segment 10); TL, total length of trunk; tu, tube.

\begin{tabular}{lll}
\hline Character & Range & Mean $($ SD; $\boldsymbol{n})$ \\
\hline TL $(\mu \mathrm{m})$ & $178.5-233.4$ & $204.9(22.1 ; 8)$ \\
MSW-6 $(\mu \mathrm{m})$ & $30.1-40.4$ & $38.5(5.9 ; 5)$ \\
MSW-6/TL $(\%)$ & $14.0-17.8$ & $18.2(4.1 ; 5)$ \\
SW-10 $(\mu \mathrm{m})$ & $14.4-27.6$ & $21.8(5.3 ; 5)$ \\
SW-10/TL $(\%)$ & $7.0-14.9$ & $10.3(3.0 ; 5)$ \\
S1 $(\mu \mathrm{m})$ & $12.6-19.2$ & $16.2(2.2 ; 8)$ \\
S2 $(\mu \mathrm{m})$ & $15.3-21.9$ & $19.5(2.2 ; 8)$ \\
S3 $(\mu \mathrm{m})$ & $18.3-24.9$ & $21.9(2.3 ; 8)$ \\
S4 $(\mu \mathrm{m})$ & $20.0-28.7$ & $23.4(2.9 ; 8)$ \\
S5 $(\mu \mathrm{m})$ & $22.7-29.5$ & $26.0(2.7 ; 8)$ \\
S6 $(\mu \mathrm{m})$ & $22.5-32.6$ & $28.1(3.3 ; 8)$ \\
S7 $(\mu \mathrm{m})$ & $29.9-34.3$ & $32.6(2.7 ; 8)$ \\
S8 $(\mu \mathrm{m})$ & $28.9-35.7$ & $32.9(2.6 ; 8)$ \\
S9 $(\mu \mathrm{m})$ & $32.2-35.9$ & $34.0(1.1 ; 8)$ \\
S10 $(\mu \mathrm{m})$ & $20.9-32.7$ & $28.3(4.4 ; 8)$ \\
S11 $(\mu \mathrm{m})$ & $20.7-26.2$ & $22.5(2.0 ; 8)$ \\
SD2 $(\mathrm{tu})(\mu \mathrm{m})$ & $9.6-15.0$ & $13.1(2.4 ; 7)$ \\
MD4 (ac) $(\mu \mathrm{m})$ & $28.5-40.3$ & $35.0(4.7 ; 7)$ \\
MD6 $(\mathrm{ac})(\mu \mathrm{m})$ & $40.1-52.7$ & $48.7(4.2 ; 7)$ \\
MD8 $(\mathrm{ac})(\mu \mathrm{m})$ & $47.2-73.8$ & $63.4(8.5 ; 8)$ \\
LV5 $(\mathrm{tu})(\mu \mathrm{m})$ & $9.8-27.0$ & $17.2(5.4 ; 8)$ \\
SL7 $(\mathrm{ac})(\mu \mathrm{m})$ & $37.8-52.4$ & $48.5(6.1 ; 7)$ \\
LV8 $(\mathrm{ac})(\mu \mathrm{m})$ & $33.4-40.3$ & $37.0(2.4 ; 8)$ \\
LV9 $(\mathrm{ac})(\mu \mathrm{m})$ & $37.7-42.5$ & $40.1(1.6 ; 8)$ \\
LTS $(\mu \mathrm{m})$ & $93.4-130.5$ & $110.3(13.4 ; 7)$ \\
LTAS $(\mu \mathrm{m})$ & $22.1-23.8$ & $23.0(0.7 ; 6)$ \\
LTS/TL $(\%)$ & $46.1-64.5$ & $53.3(3.3 ; 7)$ \\
LTAS/TL $(\%)$ & $9.5-13.3$ & $11.5(1.7 ; 6)$ \\
LTAS/LTS $(\%)$ & $17.0-25.0$ & $20.4(3.0 ; 6)$ \\
& &
\end{tabular}


935 Table 7. Summary of nature and arrangement of spines, tubes, sensory spots, glandular

936 cell outlets and nephridiopores in adults of Cephalorhyncha teresae sp. nov.

937 Abbreviations: ac, acicular spine; f, female condition of sexually dimorphic character;

938 gco1, type 1 glandular cell outlet; LA, lateral accessory; LD, laterodorsal; ltas, lateral

939 terminal accessory spine; lts, lateral terminal spine; LV, lateroventral; m, male condition

940 of sexually dimorphic character; MD, middorsal; ML, midlateral; ne, nephridiopore;

941 PD, paradorsal; ps, penile spine; SD, subdorsal; SL, sublateral; ss, sensory spot; tu,

942 tube; VL, ventrolateral.

\begin{tabular}{|c|c|c|c|c|c|c|c|c|c|}
\hline Segment & MD & PD & SD & LD & ML & SL & LA & $\mathbf{L V}$ & VL \\
\hline 1 & gco1 & & SS & SS & & & & Ss & \\
\hline 2 & gcol & ss & tu & & ss & & & & \\
\hline 3 & gco1 & Ss & ss & & & ss & & & \\
\hline 4 & $\mathrm{ac}$ & ss & & & & ss & & & \\
\hline 5 & & & & & & & & tu & ss \\
\hline 6 & $\mathrm{ac}$ & ss & & & & & & & ss \\
\hline 7 & & & ss & & & ac & & & \\
\hline 8 & $\mathrm{ac}$ & ss & & & & & & $\mathrm{ac}$ & \\
\hline 9 & gco1 & Ss & & ss & ne & & & $\mathrm{ac}$ & \\
\hline 10 & gco1 & & ss & & & & & & \\
\hline 11 & gcol & Ss & & & $\operatorname{psx} 3(\mathrm{~m})$ & & $\operatorname{ltas}(f)$ & lts & \\
\hline
\end{tabular}

943

944 Table 8. Measurements of adult Echinoderes xalkutaat sp. nov. from the Gulf of 945 California, including number of measured specimens $(n)$, mean of data and standard 946 deviation. Remarkable differences in size and/or dimension between the two sexes 947 unknown, as only females were sampled. Abbreviations: ac, acicular spine; LTAS, 948 lateral terminal accessory spine; LTS, lateral terminal spine; LV, lateroventral; MD, 949 middorsal; MSW-7, maximum sternal width (on segment 7); S, segment lengths; SW95010 , standard sternal width (on segment 10); TL, total length of trunk; tu, tube.

\begin{tabular}{lll}
\hline Character & Range & Mean $($ SD; $\boldsymbol{n})$ \\
\hline TL $(\mu \mathrm{m})$ & $282.2-303.5$ & $290.2(11.6 ; 3)$ \\
MSW-7 $(\mu \mathrm{m})$ & $48.4-48.9$ & $48.6(0.4 ; 2)$ \\
MSW-7/TL $(\%)$ & $17.1-17.2$ & $17.1(0.0 ; 2)$ \\
SW-10 $(\mu \mathrm{m})$ & $39.7-39.9$ & $39.8(0.1 ; 2)$ \\
SW-10/TL $(\%)$ & $13.9-14.1$ & $14.0(0.1 ; 2)$ \\
S1 $(\mu \mathrm{m})$ & $26.3-29.8$ & $28.0(1.7 ; 3)$
\end{tabular}




$\begin{array}{lll}\text { S2 }(\mu \mathrm{m}) & 26.1-32.5 & 29.5(3.2 ; 3) \\ \text { S3 }(\mu \mathrm{m}) & 30.1-33.9 & 32.6(1.5 ; 3) \\ \text { S4 }(\mu \mathrm{m}) & 29.4-33.2 & 31.9(2.1 ; 3) \\ \text { S5 }(\mu \mathrm{m}) & 31.3-36.6 & 34.7(2.9 ; 3) \\ \text { S6 }(\mu \mathrm{m}) & 35.0-40.8 & 37.5(3.0 ; 3) \\ \text { S7 }(\mu \mathrm{m}) & 39.5-42.0 & 41.0(1.3 ; 3) \\ \text { S8 }(\mu \mathrm{m}) & 44.5-46.9 & 45.4(1.3 ; 3) \\ \text { S9 }(\mu \mathrm{m}) & 40.9-45 & 42.6(2.1 ; 3) \\ \text { S10 }(\mu \mathrm{m}) & 34.5-36.7 & 35.2(1.2 ; 3) \\ \text { S11 }(\mu \mathrm{m}) & 23.9-31.9 & 28.6(4.2 ; 3) \\ \text { MD4 }(\mathrm{ac})(\mu \mathrm{m}) & 41.9-44.3 & 43.1(1.7 ; 2) \\ \text { MD5 }(\mathrm{ac})(\mu \mathrm{m}) & 56.0-56.0 & 56.0(0.0 ; 1) \\ \text { MD6 }(\mathrm{ac})(\mu \mathrm{m}) & 65.2-74.9 & 69.1(5.1 ; 3) \\ \text { MD7 }(\mathrm{ac})(\mu \mathrm{m}) & 70.2-71.5 & 70.9(0.6 ; 3) \\ \text { MD8 }(\mathrm{ac})(\mu \mathrm{m}) & 76.6-83.9 & 79.6(3.8 ; 3) \\ \text { LV5 }(\mathrm{tu})(\mu \mathrm{m}) & 7.7-10.3 & 9.1(1.3 ; 3) \\ \text { LV6 }(\mathrm{ac})(\mu \mathrm{m}) & 28.0-38.2 & 33.7(5.2 ; 3) \\ \text { LV7 }(\mathrm{ac})(\mu \mathrm{m}) & 42.1-43.2 & 42.7(0.8 ; 2) \\ \text { LV8 }(\mathrm{ac})(\mu \mathrm{m}) & 45.2-47.4 & 46.5(1.1 ; 3) \\ \text { LV9 }(\mathrm{ac})(\mu \mathrm{m}) & 32.1-39.3 & 35.4(3.7 ; 3) \\ \text { LTS }(\mu \mathrm{m}) & 171.3-178.6 & 175.9(4.0 ; 3) \\ \text { LTAS }(\mu \mathrm{m}) & 50.3-56.2 & 53.1(3.0 ; 3) \\ \text { LTS/TL }(\%) & 58.9-63.0 & 60.6(2.1 ; 3) \\ \text { LTAS/TL }(\%) & 17.4-19.7 & 18.3(1.3 ; 3) \\ \text { LTAS/LTS (\%) } & 28.3-32.8 & 30.2(2.3 ; 3) \\ & & \end{array}$

951

952 Table 9. Summary of nature and arrangement of spines, tubes, sensory spots, glandular 953 cell outlets and nephridiopores in adults of Echinoderes xalkutaat sp. nov. 954 Abbreviations: ac, acicular spine; f, female condition of sexually dimorphic character; 955 gco1/2, type 1/2 glandular cell outlet; LA, lateral accessory; LD, laterodorsal; ltas, 956 lateral terminal accessory spine; lts, lateral terminal spine; LV, lateroventral; MD, 957 middorsal; ML, midlateral; ne, nephridiopore; PD, paradorsal; SD, subdorsal; SL, 958 sublateral; ss, sensory spot; tu, tube; VL, ventrolateral, VM, ventromedial.

\begin{tabular}{|c|c|c|c|c|c|c|c|c|c|c|}
\hline Segment & MD & PD & SD & LD & ML & SL & LA & $\mathbf{L V}$ & VL & VM \\
\hline 1 & gco1 & & ss & ss & & ss & & & ss & \\
\hline 2 & gco1, ss & & gco2 & gco2 & & $\operatorname{gco} 2$ & & & gco2 & gco1, ss \\
\hline 3 & gco1 & & & ss & & & & & & gco1, ss \\
\hline 4 & $\mathrm{ac}$ & gco1 & & ss & & & & & & gco1 \\
\hline
\end{tabular}




\section{ACCEPTED MANUSCRIPT}

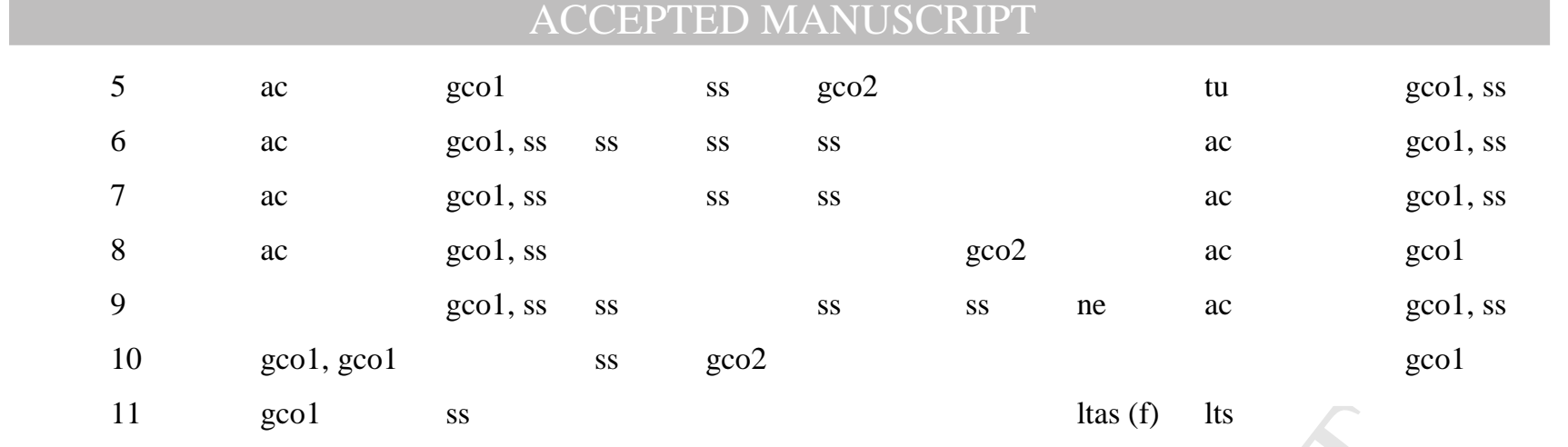

959

960

961

962

963

964

965

966

967

968

FIGURE LEGENDS

969 Fig. 1. Map showing the sampling locations of the studied kinorhynch specimens in the

970 Gulf of California (Northeast Pacific Ocean).

971 Fig. 2. Line art illustrations of male Cristaphyes fortis sp. nov. (A) Ventral overview of 972 trunk; (B) dorsal overview of trunk. Abbreviations: bsj, ball-and-socket joint; dcr, 973 dorsal cuticular ridge; dpl, dorsal placid; gco, glandular cell outlet; ldms, laterodorsal 974 muscular scar; ldse, laterodorsal seta; ldss, laterodorsal sensory spot; ldss3, laterodorsal 975 type 3 sensory spot; lts, lateral terminal spine; lvse, lateroventral seta; mdp, middorsal 976 process; pc, pachycycli; pdse, paradorsal seta; plse, paralateral seta; ppf, primary 977 pectinate fringe; ps, penile spine; S, segment (number after $\mathrm{S}$ indicates the 978 corresponding segment); sdgco, subdorsal glandular cell outlet; sdlg, subdorsal 979 longitudinal groove; sdss, subdorsal sensory spot; sdss3, subdorsal type 3 sensory spot; 980 vcr, ventral cuticular ridge; vlms, ventrolateral muscular scar; vlse, ventrolateral seta; 981 vlss, ventrolateral sensory spot; vmgco, ventromedial glandular cell outlet; vmms, 
ventromedial muscular scar; vmse, ventromedial seta; vmss, ventromedial sensory spot; vpl, ventral placid.

Fig. 3. Light micrographs showing trunk overviews and details in the mouth cone, introvert and lateral terminal spines characters of male holotype USNM 1558492 of Cristaphyes fortis sp. nov. (A) Dorsal overview of trunk; (B) ventral overview of trunk; (C) mouth cone, detail showing ring -01 of inner oral styles; (D) mouth cone, detail showing outer oral styles; (E) introvert, with detail of the first ring of primary spinoscalids (ring 01), remaining rings of regular scalids, trichoscalids; and horn-like extensions of segment 1; $(\mathrm{F})$ detail of a lateral terminal spine. Abbreviations: bsmc, basal sheath of mouth cone; h, horn-like extension; ios, inner oral style; oos, outer oral style; psc, primary spinoscalid; sc, scalid; ts, trichoscalid.

Fig. 4. Light micrographs showing details of cuticular trunk characters of segments 1-5 of male holotype USNM 1558492 of Cristaphyes fortis sp. nov., with main focus on glandular cell outlets, setae, sensory spots and cuticular processes. (A) Left half of tergal plate of segment 1; (B) right half of sternal plates of segment 1; (C) left half of tergal plate of segment 2; (D) right half of sternal plate of segment 2; (E) left half of tergal plate of segment 3; (F) right half of sternal plate of segment 3; (G) left half of tergal plate of segment 4; $(\mathrm{H})$ right half of sternal plate of segment 4; (I) left half of tergal plate of segment $5 ;(\mathrm{J})$ right half of sternal plate of segment 5 . Abbreviations: ldse, laterodorsal seta; mdp, middorsal process; pdse, paradorsal seta; plse, paralateral seta; sdlg, subdorsal longitudinal groove; vcr, ventral cuticular ridge; vlse, ventrolateral seta; sensory spots are marked as closed circles, and glandular cell outlets as dashed circles; numbers after abbreviation indicate the corresponding segment.

Fig. 5. Light micrographs showing details of cuticular trunk characters of segments 611 of male holotype USNM 1558492 of Cristaphyes fortis sp. nov., with main focus on glandular cell outlets, setae, sensory spots and cuticular processes. (A) Left half of tergal plate of segment 6; (B) right half of sternal plate of segment 6; (C) left half of tergal plate of segment 7; (D) right half of sternal plate of segment 7; (E) left half of tergal plate of segment 8; (F) right half of sternal plate of segment 8; (G) left half of tergal plate of segment 9; $(\mathrm{H})$ right half of sternal plate of segment 9; (I) left half of tergal plate of segment 10; $(\mathrm{J})$ right half of sternal plate of segment 10; $(\mathrm{K})$ left half of tergal plate of segment 11; (L) right half of sternal plate of segment 11. Abbreviations: ldse, laterodorsal seta; mdp, middorsal process; pdse, paradorsal seta; ps, penile spine; 
1015

1016

1017

1018

1019

1020

1021

1022

1023

1024

1025

1026

1027

1028

1029

1030

1031

1032

1033

1034

1035

1036

1037

1038

1039

1040

1041

1042

1043

1044

1045

1046

1047

ss3, type 3 sensory spot; vcr, ventral cuticular ridge; vlse, ventrolateral seta; vmse, ventromedial seta; sensory spots are marked as closed circles, and glandular cell outlets as dashed circles; numbers after abbreviation indicate the corresponding segment.

Fig. 6. Line art illustrations of Higginsium mazatlanensis sp. nov. (A) Male, ventral overview of trunk; (B) male, dorsal overview of trunk; (C) female, ventral overview of segments 1-2; (D) female, ventral overview of segments 10-11. Abbreviations: bsj, ball-and-socket joint; dpl, dorsal placid; gco, glandular cell outlet; ia, intracuticular atria; ldms, laterodorsal muscular scar; ldse, laterodorsal seta; ldss, laterodorsal sensory spot; lvse, lateroventral seta; lvss, lateroventral sensory spot; mde, middorsal elevation; mdp, middorsal process; pc, pachycycli; pdse, paradorsal seta; pdss, paradorsal sensory spot; plse, paralateral seta; ppf, primary pectinate fringe; ps, penile spine; pvap, paraventral apodeme; sdgco, subdorsal glandular cell outlet; sdse, subdorsal seta; sdss, subdorsal sensory spot; sdss3, subdorsal type 3 sensory spot; spf, secondary pectinate fringe; vcr, ventral cuticular ridge; vlgco, ventrolateral glandular cell outlet; vlse, ventrolateral seta; vlss, ventrolateral sensory spot; vmgco, ventromedial glandular cell outlet; vmms, ventromedial muscular scar; vmse, ventromedial seta; vmss, ventromedial sensory spot; vmt, ventromedial tube; vpl, ventral placid.

Fig. 7. Light micrographs showing trunk overviews and details in the neck of male holotype USNM 1558497 of Higginsium mazatlanensis sp. nov. (A) Dorsal overview of trunk; (B) ventral overview of trunk; (C) dorsal view of neck, with detail in the dorsal placids; (D) ventral view of the neck, with detail in the ventral placids. Abbreviations: dpl, dorsal placid; vpl, ventral placid.

Fig. 8. Light micrographs showing details of cuticular trunk characters of segments 1-5 of male holotype USNM 1558497 of Higginsium mazatlanensis sp. nov., with main focus on glandular cell outlets, sensory spots, setae, cuticular elevations and tubes. (A) Left half of tergal plate of segment 1; (B) right half of sternal plates of segment 1; (C) left half of tergal plate of segment 2; (D) right half of sternal plates of segment 2; (E) left half of tergal plate of segment 3; (F) right half of sternal plates of segment 3; (G) left half of tergal plate of segment 4; $(\mathrm{H})$ right half of sternal plates of segment 4; (I) left half of tergal plate of segment 5; (J) right half of sternal plates of segment 5. Abbreviations: ldse, laterodorsal seta; $\mathrm{m}$, male condition of sexually dimorphic character; mde, middorsal elevation; pdse, paradorsal seta; plse, paralateral seta; sdse, subdorsal seta; vlse, ventrolateral seta; vmse, ventromedial seta; vmt, ventromedial 
1048

1049

1050

1051

1052

1053

1054

1055

1056

1057

1058

1059

1060

1061

1062

1063

1064

1065

1066

1067

1068

1069

1070

1071

1072

1073

1074

1075

1076

1077

1078

1079

1080

tube; sensory spots are marked as closed circles, and glandular cell outlets as dashed circles; numbers after abbreviation indicate the corresponding segment.

Fig. 9. Light micrographs showing details of cuticular trunk characters of segments 611 of male holotype USNM 1558497 of Higginsium mazatlanensis sp. nov., with main focus on glandular cell outlets, sensory spots, setae, cuticular elevations and cuticular processes. (A) Left half of tergal plate of segment 6; (B) right half of sternal plates of segment 6; (C) left half of tergal plate of segment 7; (D) right half of sternal plates of segment 7; (E) left half of tergal plate of segment 8; (F) right half of sternal plates of segment 8; $(\mathrm{G})$ left half of tergal plate of segment 9; $(\mathrm{H})$ right half of sternal plates of segment 9; (I) left half of tergal plate of segment 10; (J) right half of tergal and sternal plates of segment 10; (K) left half of tergal plate of segment 11; (L) right half of tergal and sternal plates of segment 11. Abbreviations: ldse, laterodorsal seta; lvse, lateroventral seta; mde, middorsal elevation; mdp, middorsal process; pdse, paradorsal seta; ps, penile spine; ss3, type 3 sensory spot; vlse, ventrolateral seta; vmse, ventromedial seta; sensory spots are marked as closed circles, and glandular cell outlets as dashed circles; numbers after abbreviation indicate the corresponding segment.

Fig. 10. Line art illustrations of Cephalorhyncha teresae sp. nov. (A) Ventral overview of female trunk; (B) dorsal overview of female trunk; (C) ventral view of male segments 10-11; (D) dorsal view of male segments 10-11. Abbreviations: dpl, dorsal placid; ldss, laterodorsal sensory spot; ltas, lateral terminal accessory spine; lts, lateral terminal spine; lvs, lateroventral spine; lvss, lateroventral sensory spot; lvt, lateroventral tube; mdgco1, middorsal type 1 glandular cell outlet; mds, middorsal spine; mdtf, middorsal tuft; mlne, midlateral nephridiopore; mlss, midlateral sensory spot; mvpl, midventral placid; pdss, paradorsal sensory spot; ppf, primary pectinate fringe; ps, penile spine; sdss, subdorsal sensory spot; sdt, subdorsal tube; sls, sublateral spine; slss, sublateral sensory spot; spf, secondary pectinate fringe; te, tergal extension; tsp, trichoscalid plate; vlss, ventrolateral sensory spot.

Fig. 11. Light micrographs showing trunk overviews and details in the head, neck, segment 2 and lateral terminal and lateral terminal accessory spines of female holotype USNM 1558501 of Cephalorhyncha teresae sp. nov. (A) Dorsal overview of trunk; (B) ventral overview of trunk; (C) ventral view of segment 11, with detail in the lateral terminal and the lateral terminal accessory spines; (D) mouth cone, with detail in the outer oral styles; (E) introvert, with detail in the primary spinoscalids; (F) dorsal view of 
1081

1082

1083

1084

1085

1086

1087

1088

1089

1090

1091

1092

1093

1094

1095

1096

1097

1098

1099

1100

1101

1102

1103

1104

1105

1106

1107

1108

1109

1110

1111

1112

1113

neck, with detail in the placids and the trichoscalid plates; $(G)$ ventral view of neck, with detail in the placids; $(\mathrm{H})$ ventral view of segment 2. Abbreviations: ltas, lateral terminal accessory spine; lts, lateral terminal spine; mvp, midventral placid; oos, outer oral style; psc, primary spinoscalid; tsp, trichoscalid plate.

Fig. 12. Light micrographs showing details of cuticular trunk characters of segments 111 of female holotype USNM 1558501 of Cephalorhyncha teresae sp. nov., with main focus on glandular cell outlets, sensory spots, nephridiopores, tubes and spines. (A) Left half of tergal plate of segments 1-4; (B) right half of sternal plates of segments 1-4; (C) left half of tergal plate of segments 5-8; (D) right half of sternal plates of segments 5-8; (E) left half of tergal plate of segments 9-11; (F) right half of sternal plates of segments 9-11. Abbreviations: lvt, lateroventral tube; lvs, lateroventral spine; mds, middorsal spine; mlne, midlateral nephridiopore; sdt, subdorsal tube; sls, sublateral spine; sensory spots are marked as closed circles, and glandular cell outlets as dashed circles; numbers after abbreviation indicate the corresponding segment.

Fig. 13. Line art illustrations of Echinoderes xalkutaat sp. nov. (A) Ventral overview of female trunk; (B) dorsal overview of female trunk. Abbreviations: dpl, dorsal placid; lane, lateral accessory nephridiopore; ldgco2, laterodorsal type 2 glandular cell outlet; ldss, laterodorsal sensory spot; ltas, lateral terminal accessory spine; lts, lateral terminal spine; lvs, lateroventral spine; lvt, lateroventral tube; mdgco1, middorsal type 1 glandular cell outlet; mds, middorsal spine; mdss, middorsal sensory spot; mlgco2, midlateral type 2 glandular cell outlet; mlss, midlateral sensory spot; mvp, midventral placid; pdgco1, paradorsal type 1 glandular cell outlet; pdss, paradorsal sensory spot; ph, patch of hairs; ppf, primary pectinate fringe; sdgco2, subdorsal type 2 glandular cell outlet; sdss, subdorsal sensory spot; slgco2, sublateral type 2 glandular cell outlet; slss, sublateral sensory spot; te, tergal extension; tsp, trichoscalid plate; vlgco2, ventrolateral type 2 glandular cell outlet; vlss, ventrolateral sensory spot; vmgco1, ventromedial type 1 glandular cell outlet; vmss, ventromedial sensory spot.

Fig. 14. Light micrographs showing trunk overview and detail in the head and neck of female holotype USNM 1558509 of Echinoderes xalkutaat sp. nov. (A) Overview of trunk, showing the lateral and ventral regions of the cuticular plates; (B) mouth cone, with detail of the outer oral styles; (C) introvert, with detail of a primary spinoscalid; (D) overview of introvert, showing the rings of regular scalids; (E) overview of neck, showing some ventral and lateral placids. Abbreviations: bs, basal sheath; bsf, basal 
1114

1115

1116

1117

1118

1119

1120

1121

1122

1123

1124

1125

1126

1127

1128

1129

1130

1131

1132

1133

1134

1135

1136

1137

1138

1139

1140

1141

1142

1143

1144

1145

1146

sheath's fringe; dp, distal end piece; mvp, midventral placid; oos, outer oral style; sc, scalid; tsp, trichoscalid plate.

Fig. 15. Light micrographs showing details of cuticular trunk characters of segments 15 of female holotype USNM 1558509 of Echinoderes xalkutaat sp. nov., with main focus on spines, tubes, sensory spots and glandular cell outlets. (A) Left half of ring plate of segment 1; (B) right half of ring plate of segment 1 ; (C) left half of ring plate of segment 2; (D) right half of ring plate of segment 2; (E) left half of tergal plate of segment 3; (F) right sternal plate of segment 3; (G) left half of tergal plate of segment 4; (H) right sternal plate of segment 4; (I) left half of tergal plate of segment 5; (J) right sternal plate of segment 5. Abbreviations: ldgco2, laterodorsal type 2 glandular cell outlet; ldss, laterodorsal sensory spot; lvt, lateroventral tube; mdgco1, middorsal type 1 glandular cell outlet; mds, middorsal spine; mdss, middorsal sensory spot; pgco1, paradorsal type 1 glandular cell outlet; sdgco2, subdorsal type 2 glandular cell outlet; sdss, subdorsal sensory spot; slgco2, sublateral type 2 glandular cell outlet; slss, sublateral sensory spot; vlgco2, ventrolateral type 2 glandular cell outlet; vlss, ventrolateral sensory spot; vmgco1, ventromedial type 1 glandular cell outlet; vmss, ventromedial sensory spot; sensory spots are marked as closed circles, and glandular cell outlets as dashed circles; numbers after abbreviation indicate the corresponding segment.

Fig. 16. Light micrographs showing details of cuticular trunk characters of segments 611 of female holotype USNM 1558509 of Echinoderes xalkutaat sp. nov., with main focus on spines, nephridiopores, sensory spots and glandular cell outlets. (A) Left half of tergal plate of segment 6; (B) right sternal plates of segments 6-8; (C) left half of tergal plate of segment 7; (D) left half of tergal plate of segment 8; (E) left half of tergal plate of segment 9; (F) right sternal plate of segment 9; (G) left half of tergal plates of segments 10-11; (H) right sternal plates of segments 10-11; (I) dorsal view of segment 11, with main focus on tergal extensions. Abbreviations: lane, lateral accessory nephridiopore; ldgco2, laterodorsal type 2 glandular cell outlet; ldss, laterodorsal sensory spot; lvs, lateroventral spine; mdgco1, middorsal type 1 glandular cell outlet; mds, middorsal spine; mlss, midlateral sensory spot; pdgco1, paradorsal type 1 glandular cell outlet; pdss, paradorsal sensory spot; sdss, subdorsal sensory spot; slgco2, sublateral type 2 glandular cell outlet; slss, sublateral sensory spot; te, tergal extension; vmgco1, ventromedial type 1 glandular cell outlet; vmss, ventromedial sensory spot; 
1147 sensory spots are marked as closed circles, and glandular cell outlets as dashed circles;

1148 numbers after abbreviation indicate the corresponding segment.

1149 


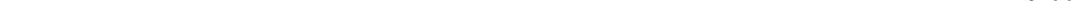


A

tsp mvpl Ivss

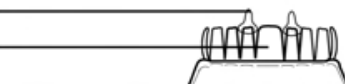

slss
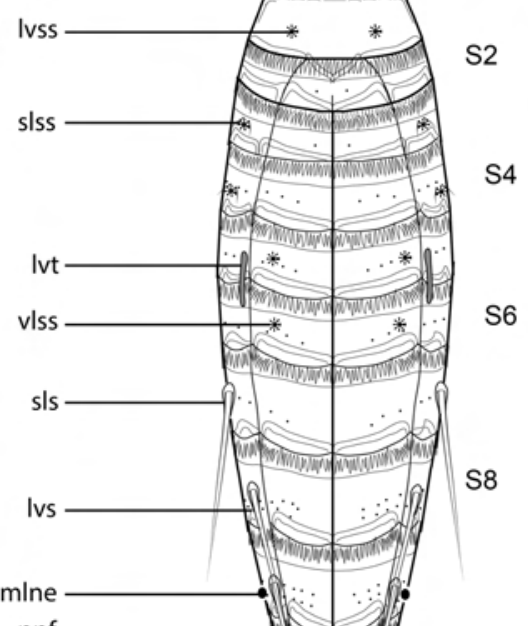

ppf spf

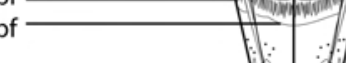

S10 Its

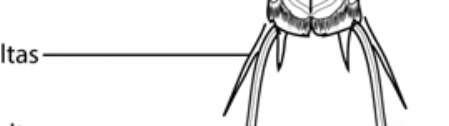

ps1 ps2 ps3 
B
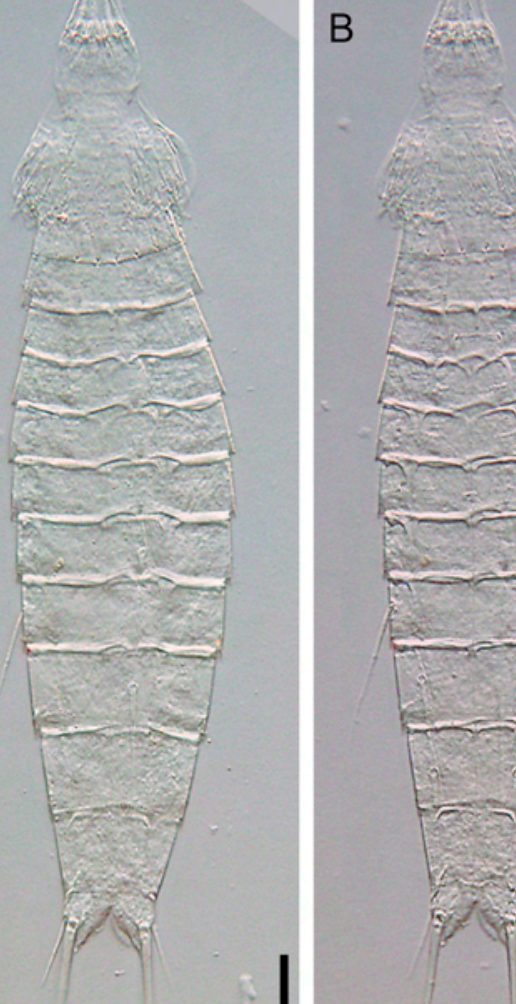

$50 \mu \mathrm{m}$

D

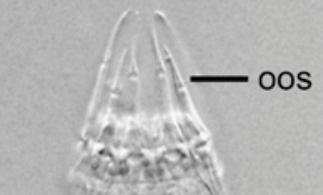

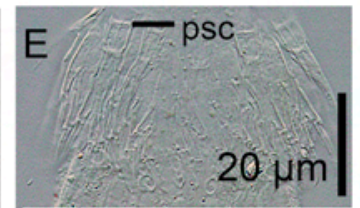

C $=20 \mu \mathrm{m}$
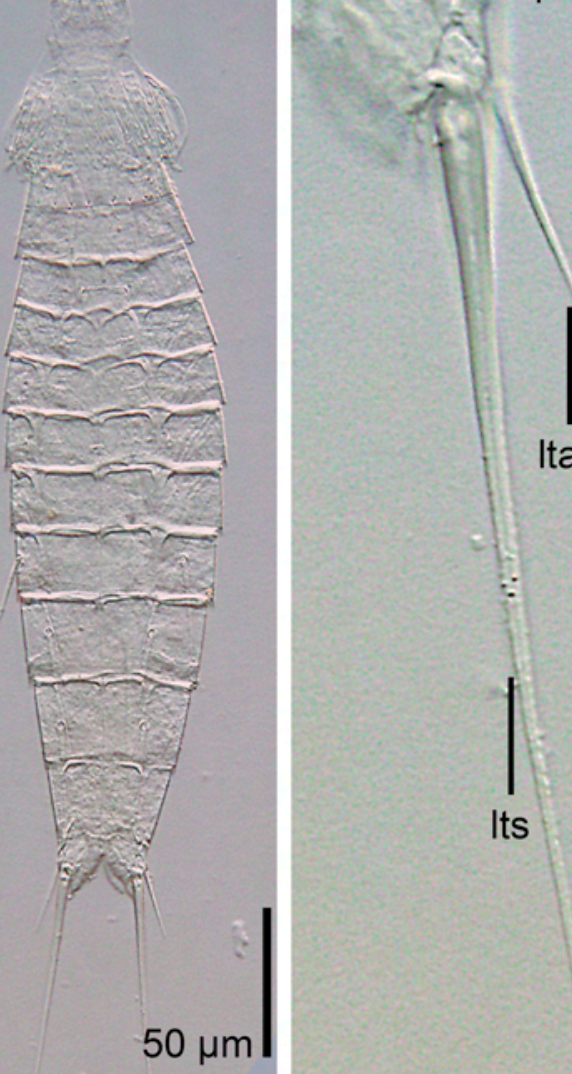

Itas

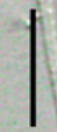

Its
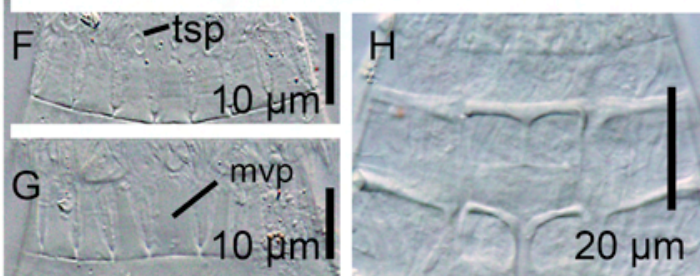


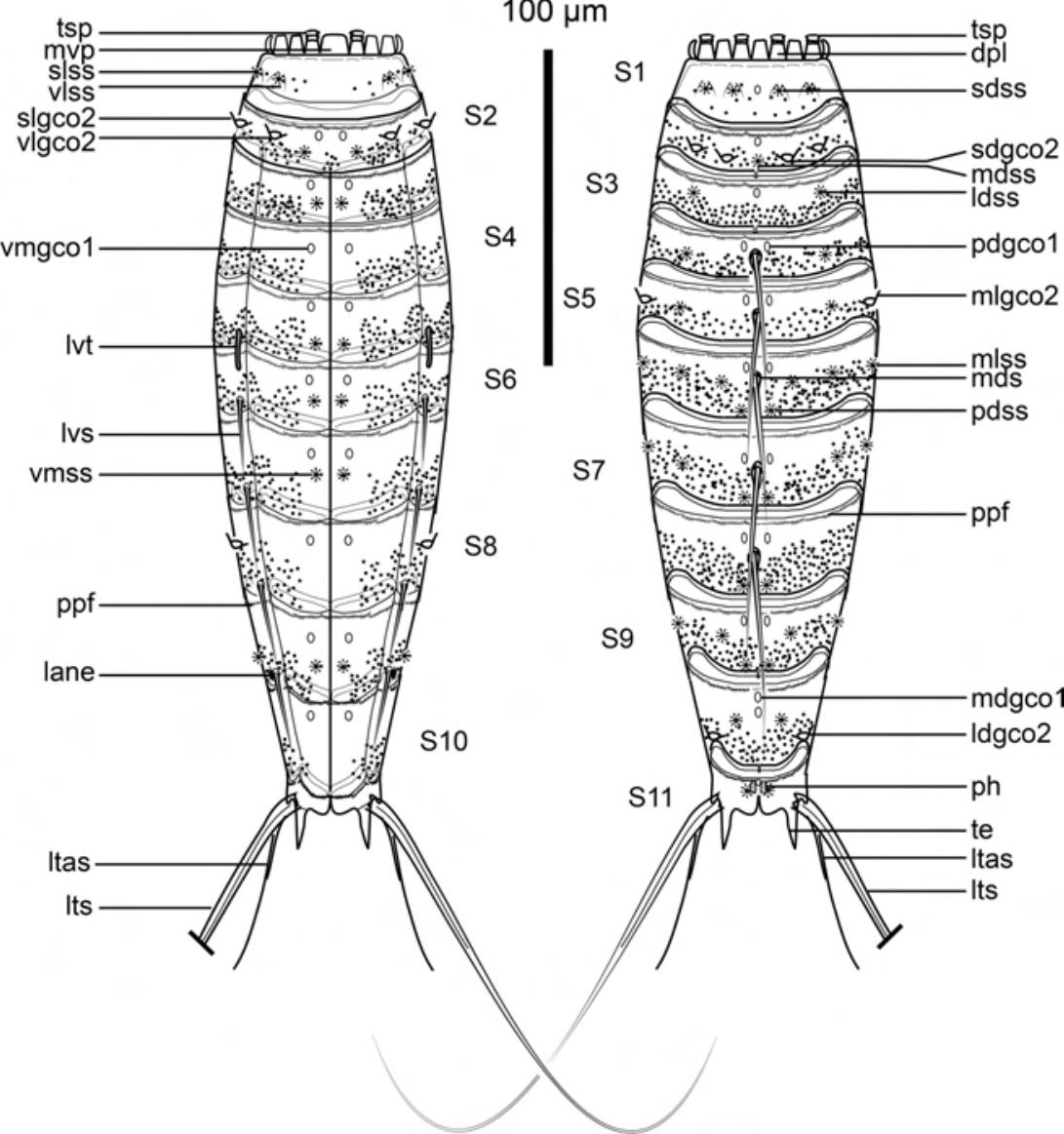




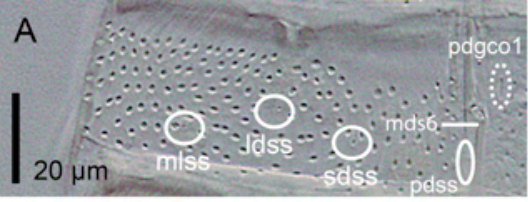

C

$\therefore \therefore 0$ nosi $20 \mu \mathrm{m}$ mlss $\because$ dos $\because \cdots \cdots$ mass
B vmgcot

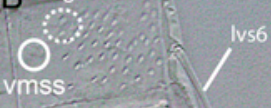

D

$20 \mu \mathrm{m}$

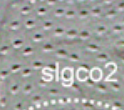

$\because$ slgco2 $\because \because \because \cdots$

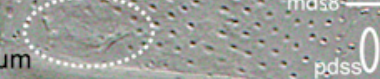

E

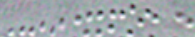

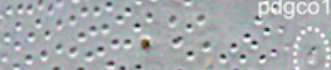

$\therefore ;, \because \cdots$,

$\therefore \because 08 \% \therefore$ sdss $\because 4$

$\because \therefore$ inlss $* \ldots \therefore$ odss

$20 \mu \mathrm{m}$

G

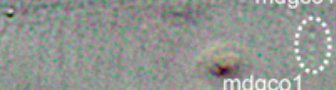

$y_{0}=0$
$n_{0}=0$

$\because-0$ sodss $, \ldots, 0$

Idgco2

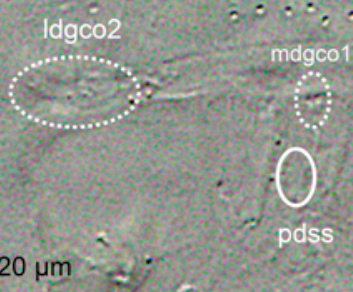

pdgco1

$\therefore$

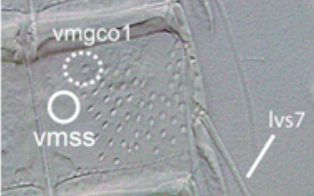

1. $\because$ vingcot
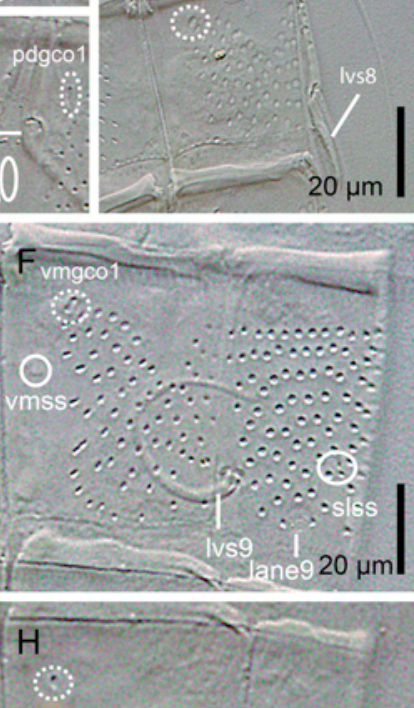

vmgco1

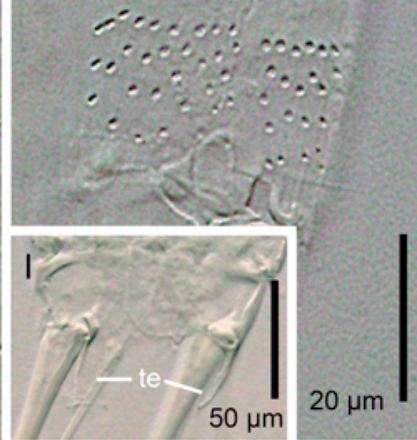


A

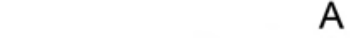

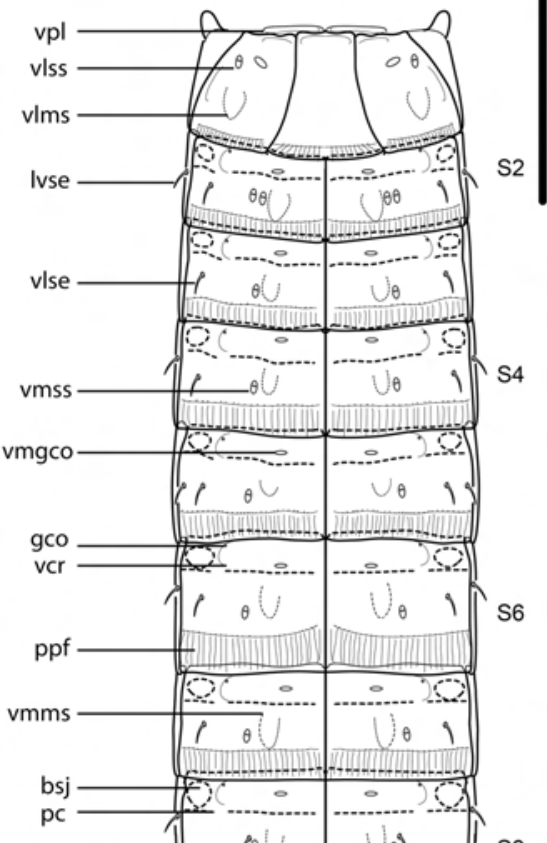

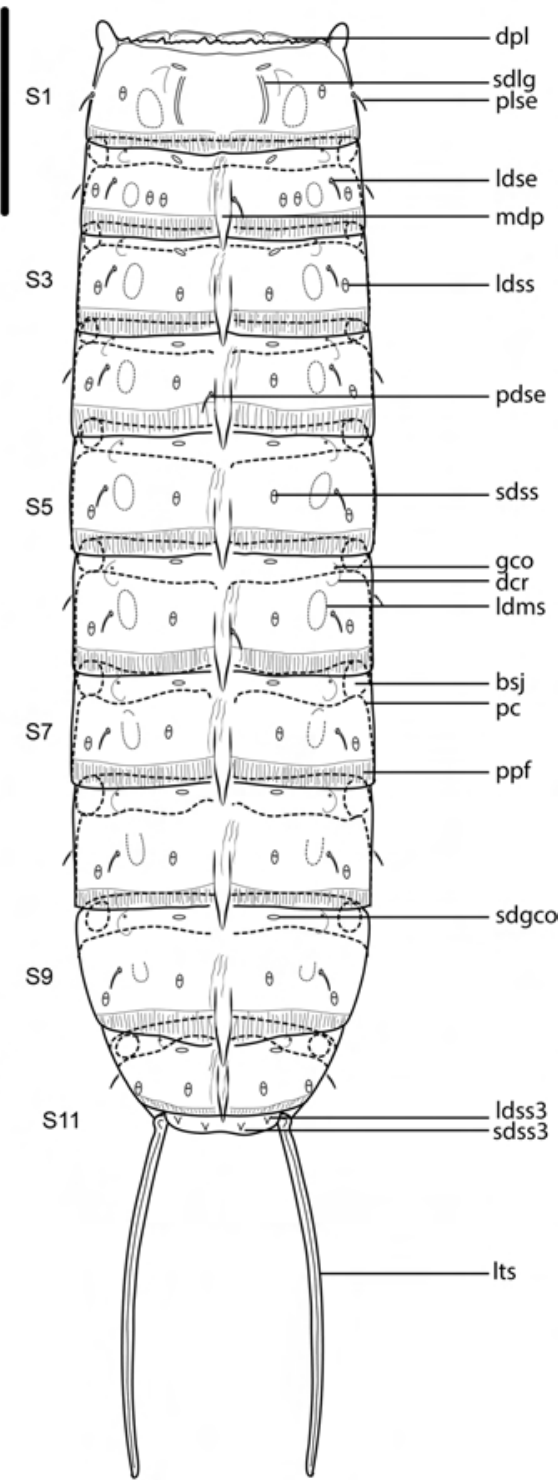


$A \gg$

No

(axis)

sisisens

hiv 1

arovitis

B.s.

EDir 4

$25,5=5$

Win 35

fixn: 8

No wi in

$(x+2,8)$

[isin 83

ina

fed $x+4$

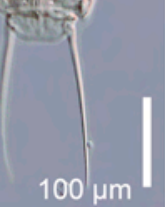

B<smiles>[Mg][Mg]</smiles>

Mindet

(2) 250

(fiv

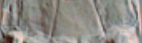

som $1 \times 3$

o. $65,+2$

Wey 40

Mn $-3=$

Aevioling

$6 x+5)$ is

Wer $x$ ( Bas

tax $x$

$(4045)$ in

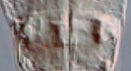

nestest

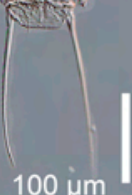

$100 \mu \mathrm{m}$
C

ios(ring -01)
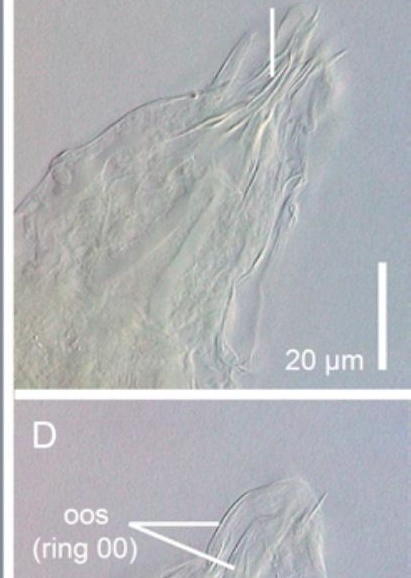

$20 \mu \mathrm{m}$

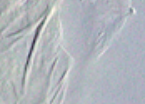

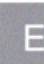

bsmc
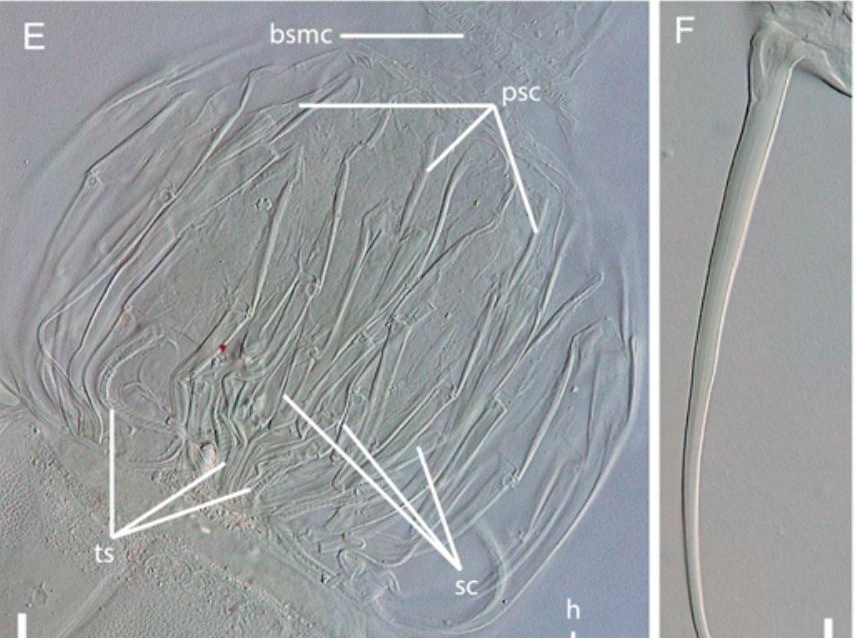
$\mathrm{psC}$ 


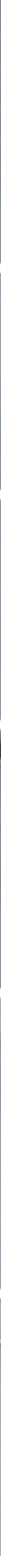




\section{A}

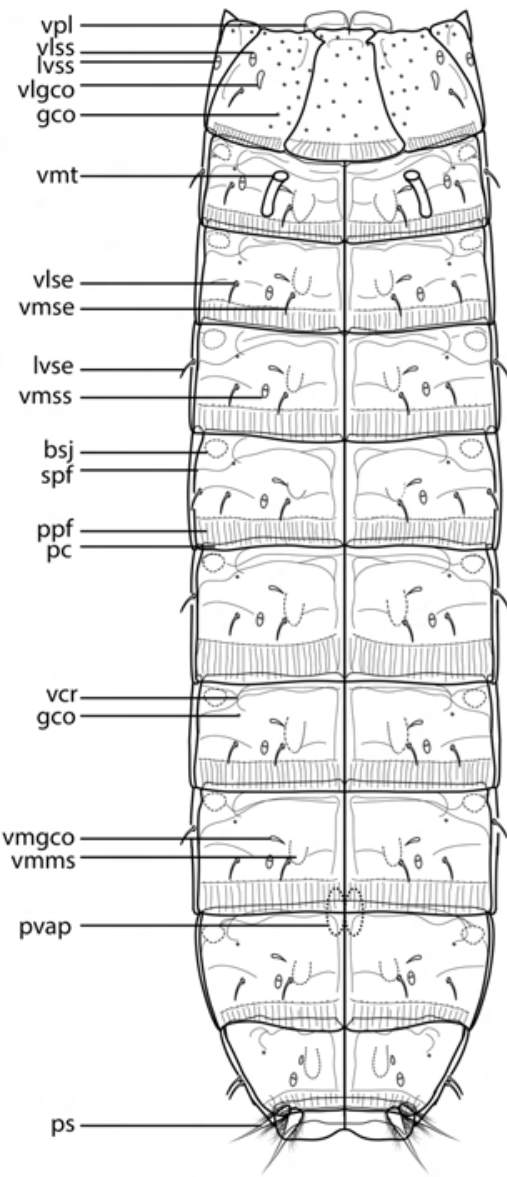

C

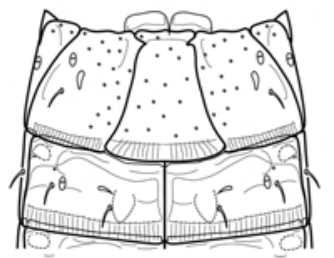

$100 \mu \mathrm{m}$

S2

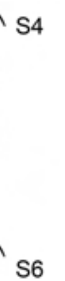

S8

S7
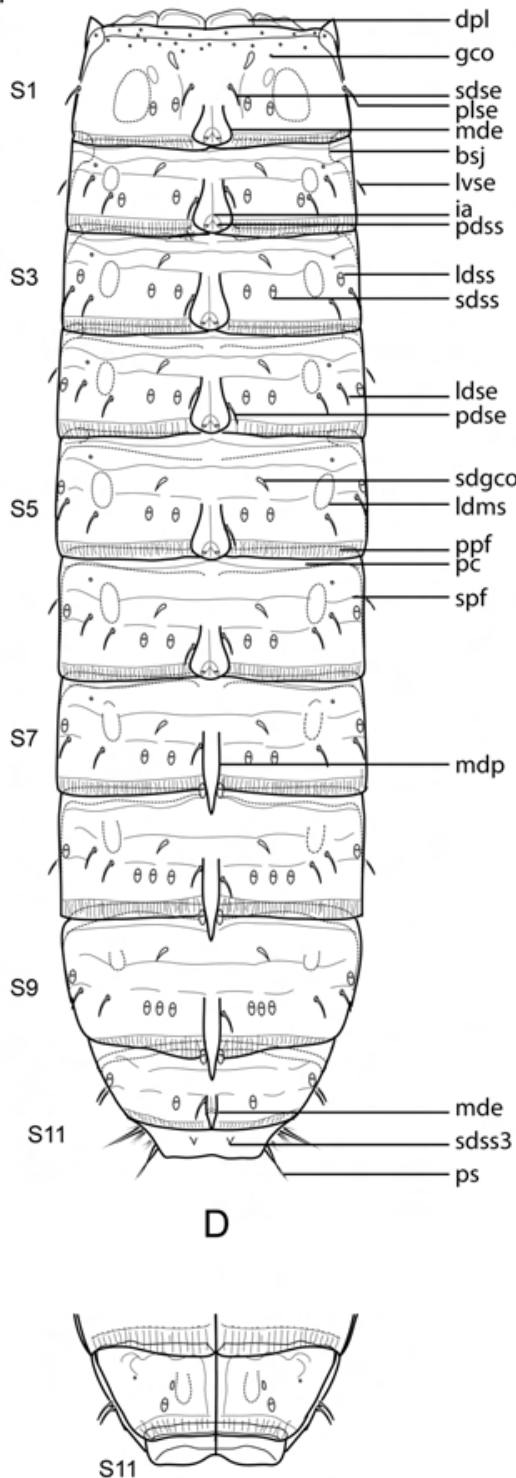
A

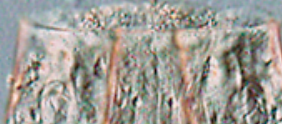

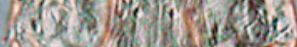

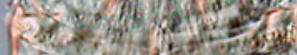
r.t. - ortin sont 18. (x) 1.x It

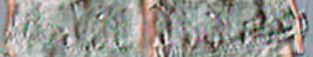
(2) Vento (x) 10

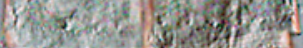
$(23)$, 1,19 (i) a nu in wity

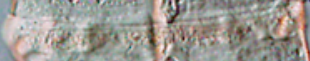

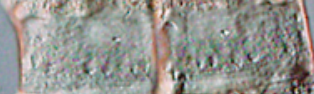
(4) conis in Q. $1 \mathrm{x} \cdot \mathrm{s}$

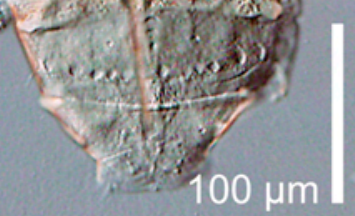

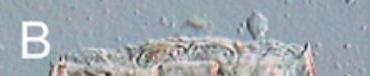

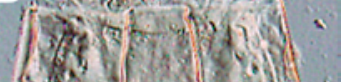

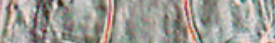
1)

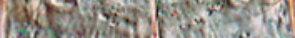

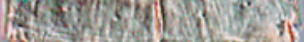

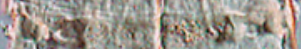

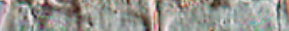

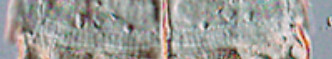

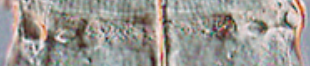

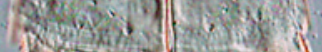

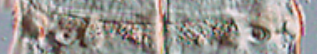

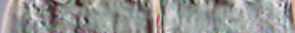
whis

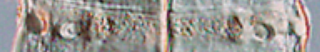
if ris

W

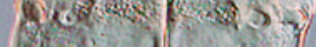

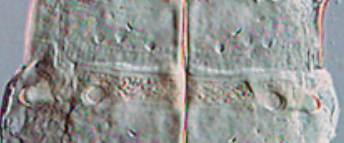

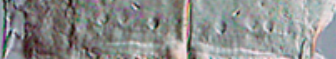

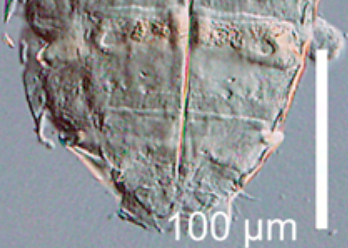

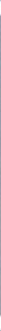

D

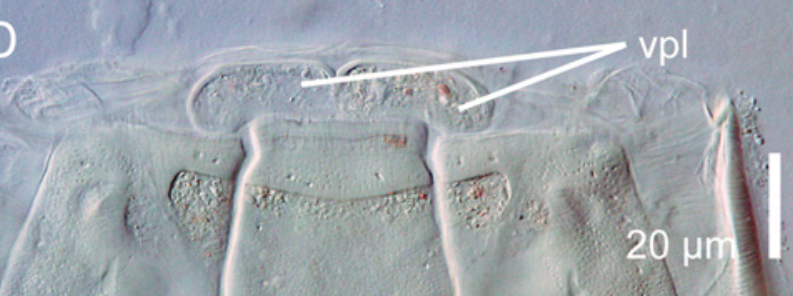


$\mathrm{A}$

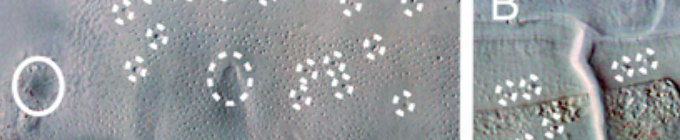

i.

plse1

$20 \mu \mathrm{m}$

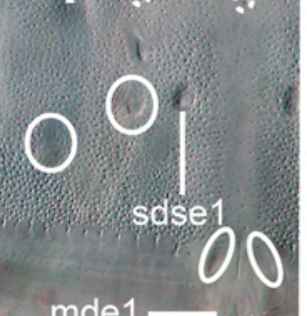

angse

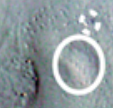

in $0^{\circ}$

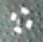

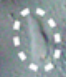

Waks

$20 \mu \mathrm{m}$

C

$10:$

O

Idsê2:

$20 \mathrm{~mm}$

mde2

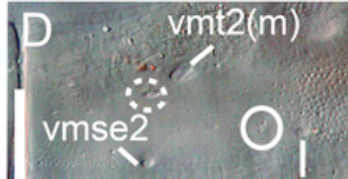

vise2
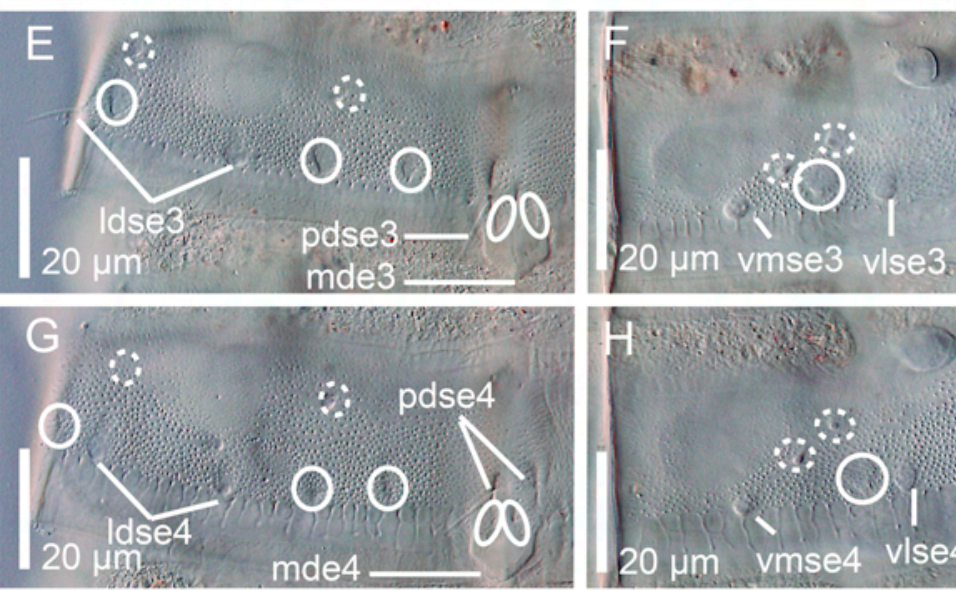

Hiris $(x)$

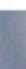

(1)

8

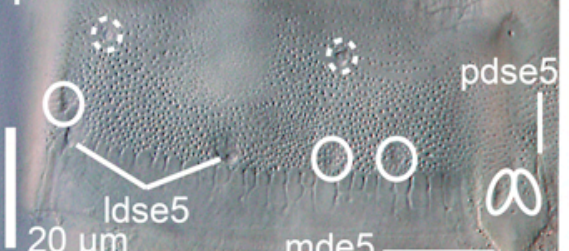

00

pdse2

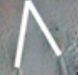

$20 \mu \mathrm{m}$

\section{rat}



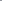